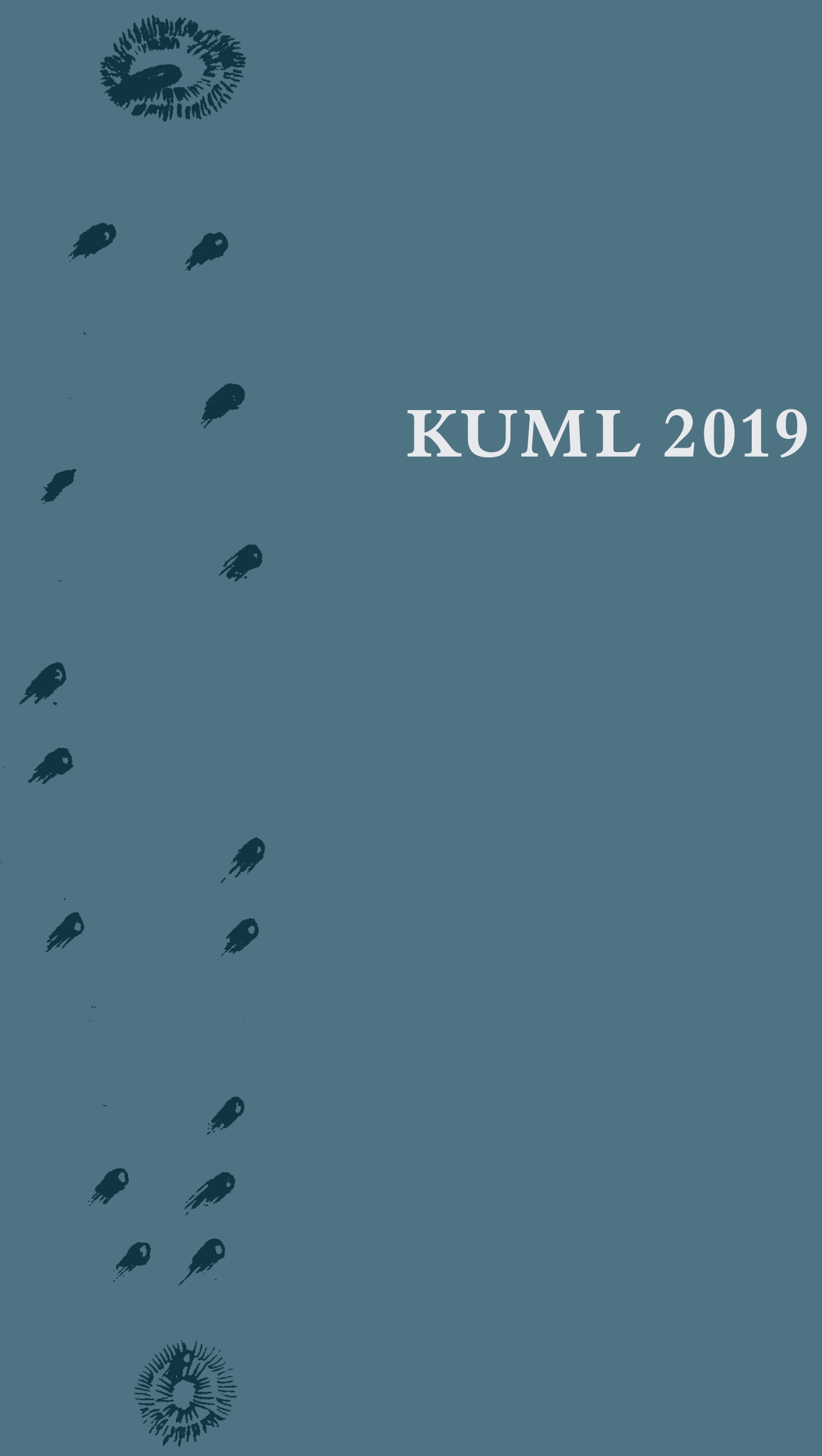

KUML 2019 


\section{KUML 2019}

Årbog for Jysk Arkæologisk Selskab

With summaries in English

I kommission hos Aarhus Universitetsforlag 


\title{
Bronzealderens hjortetaksøkser - datering og deponeringsforhold
}

\author{
AF LISE FROST, GRY H. BARFOD \& MARIE KANSTRUP
}

Forskning i depotfund fra den nordiske bronzealder har traditionelt set og med god grund haft fokus på periodens mange genstande af bronze og guld. ${ }^{1}$ Det er derfor et noget overset fænomen, at der i depotfundene også findes genstande af sten, uld, bast, træ, beg, knogle mv. Emnet for denne artikel er netop en af disse lidt glemte genstandstyper, nemlig hjortetaksøkser fra Danmarks bronzealder. ${ }^{2}$

Her er formålet for det første kort at fremlægge disse hjortetaksøkser med deres karakteristika, et par metalanalyser af ornamentikelementerne samt ${ }^{14} \mathrm{C}$ dateringer af nogle hjortetaksøkser. For det andet er formålet på den baggrund at vurdere hjortetaksøkser som dele af den store og varierede gruppe af enkeltdeponerede genstande, der typisk har været nedlagt som led i rituelle sammenhænge på udvalgte steder i landskabet. Her findes en meget stor del af fundene ved åer og i vådområder i tilknytning hertil, og således kan de også ses som en del af det velkendte flodfundsfænomen, som kendes fra store dele af Europa. ${ }^{3}$

Hjortetaksøkser forbindes normalt med den ældre stenalder. I dansk neolitikum forsvinder økser af kronhjortetak på det nærmeste helt ud af inventaret for så mere end 2.000 år senere at dukke op igen i bronzealderen i lidt anderledes udformninger. Med jernalderen forsvinder øksetypen igen, mens gevir som råmateriale stadig anvendes til bl.a. kamme, håndtag og bidselstænger. ${ }^{4}$ Det har imidlertid ikke været klart, om hjortetaksøkser forekommer igennem hele bronzealderen, og derfor er ${ }^{14} \mathrm{C}$-dateringer væsentlige.

Hjortetaksøkser fra bronzealderen kan forekomme i bosættelsessammenhænge, men findes typisk i moser, åer og engmiljøer. De er dermed en del af den meget store og varierede gruppe af enkeltdeponerede genstande, som forekommer igennem hele bronzealderen og i oldtiden i øvrigt i form af økser, sværd og halsringe mv. ${ }^{5}$ Nedlæggelsen som enkeltdeponeringer og dermed uden kontekst betyder også, at det først omkring 1900-tallet bliver klart, at de 


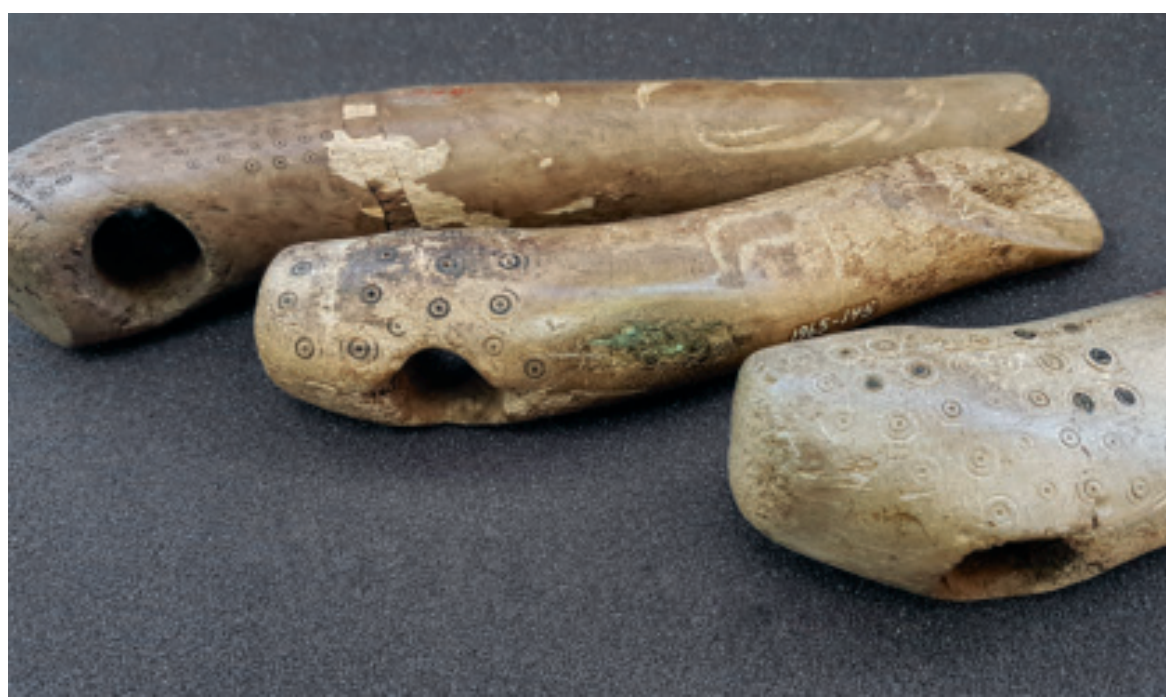

Fig. 1. Tre eksempler på hjortetaksøkser fra bronzealderen med den karakteristiske punktcirkelornamentik. De tre viste hjortetaksøkser er alle dateret. Stykket forrest til højre er fundet $i$ et engstykke ned mod Gudenåen ved Boring nær Horsens (se også fig. 12 med målestok, 13 og 14) og er fra sen xldre bronzealder $\left(3006 \pm 28{ }^{14} \mathrm{C}\right.$ år bp, fig. 15 nr. 4). Øksen i midten, der måler $22 \mathrm{~cm}$ i længden, er et åfund fra Kalum Bæk i Vendsyssel, der daterer sig til den ældre bronzealders midte $\left(3078 \pm 30{ }^{14} \mathrm{C}\right.$ år bp, fig. $15 \mathrm{nr}$. 2), mens den bageste økse er fra en mose ved Jelstrup i Vendsyssel (se også fig. 2, 9 med målestok, 10 og 11), som er dateret til yngre bronzealder $\left(2854 \pm 29{ }^{14} \mathrm{C}\right.$ år bp, fig. 15 nr. 11). - Foto: Anna Tjelldén, Moesgaard Museum.

Three examples of Bronze Age antler axes with the characteristic point-circle ornamentation. All three were dated during the project. The axe front right was found in a meadow/ bog near the Gudenå river at Boring near Horsens (figs. 12-14) and dates from the end of the Early Bronze Age $\left(3006 \pm 28{ }^{14} \mathrm{C}\right.$ years bp, fig. 15 no. 4). The axe in the middle is a river find from Kalum Bæk in Vendsyssel and dates from the middle of the Early Bronze Age $\left(3078 \pm 30{ }^{14} \mathrm{C}\right.$ years bp, fig. 15 no. 2), while the axe at the rear was found in a bog near Jelstrup in Vendsyssel (see also figs. 2, 9-11) and dates from the Late Bronze Age $\left(2854 \pm 29{ }^{14} \mathrm{C}\right.$ years bp, fig. 15 no. 11$)$.

også kan være fra bronzealderen, hvilket især skyldes deres ornamentik, som typisk består af punkt-cirkelornamenter (se fig. 1). ${ }^{6}$ Bronzealderens hjortetaksøkser er siden omtalt kort i forbindelse med ældre oldsagsoversigter, i oversigtslitteratur og i kortere fundmeddelelser. ${ }^{7}$ J.-P. Schmidt har desuden i 1995 behandlet punktcirkelornamenterede hjortetaksøkser fra Nordvesteuropa. ${ }^{8}$ Gruppen af danske hjortetaksøkser med og uden ornamentik har dog aldrig tidligere fået en samlet fremlæggelse. ${ }^{9}$ 


\section{Udbredelse}

Der er registreret 155 danske fund af hjortetaksøkser fra bronzealderen, og de fordeler sig på 139 lokaliteter (fig. 2). ${ }^{10}$ Fund af sådanne organiske genstande er selvsagt afhængig af gode bevaringsforhold og er koncentreret bl.a. i Vendsyssel, i dele af det østlige Jylland, på Fyn og i det vestlige og nordlige Sjælland. I store dele af det sydlige og centrale Jylland er der langt imellem fundene, og der er heller ikke registreringer fra Bornholm. Der kan være flere årsager til, at nogle områder er fundtomme. Det kan f.eks. hænge sammen med vekslende bevaringsforhold og jordens kemi, men der kan også være oversete hjortetaksøkser fra bronzealderen, der er registreret som stenalder. Fig. 3 viser fundfordelingen, som tydeligvis hovedsagelig knytter sig til vand med moser, vådområder, søer, åer og desuden med få fund fra fjord og hav. Dertil kommer et enkelt gravfund fra en høj på Sindal Hede, hvor oplysningerne er fåtallige, men hvor der i midten af 1800-tallet skulle være fundet en hjortetaksøkse under en bøjlenål af bronze. ${ }^{11}$ I bopladskategorien indgår 24 hjortetaksøkser, som fordeler sig på samlet set 16 yngre bronzealderbosættelser fra Fyn og Sjælland, hvor de primært er dukket op i gruber. I det jyske materiale kendes indtil videre ikke fund af hjortetaksøkser fra bosættelsessammenhænge.

125 af de 155 økser er enkeltfund, mens der på 12 lokaliteter er registreret to hjortetaksøkser, og på to lokaliteter er der registreret tre økser inden for samme museumsregistrering.

Uden for Danmark findes hjortetaksøkser fra bronzealderen primært i det nordlige Tyskland, men de kendes også fra Holland, Baltikum, Sverige og langt sydligere i eksempelvis Slovakiet, Østrig og Ungarn. ${ }^{12}$ Her kan der i lighed med det danske materiale både være tale om fund fra vand og vådbundsområder og fund fra bosættelsessammenhænge.

\section{Øksernes karakteristika}

Bronzealderens hjortetaksøkser kan både være upolerede og polerede og være med eller uden ornamentik. Skafthullerne er runde, lettere ovale eller firkantede, hvor sidstnævnte gælder for ca. 1/3 af det samlede antal økser. ${ }^{13}$ De firkantede skafthuller har været medvirkende årsag til, at disse økser er blevet dateret til bronzealderen, idet de indimellem har spor efter hak og kanter, som ser ud til at skyldes brug af metalmejsler (se f.eks. fig. 21a og b). Generelt set er det økser med skafthul igennem den nederste sprosse på geviret - den såkaldte øjesprosse - som dominerer. Og det er et kendetegn for de ikke-mesolitiske hjortetaksøkser, at æggen er parallel med skafthullet, og at de derfor har været 


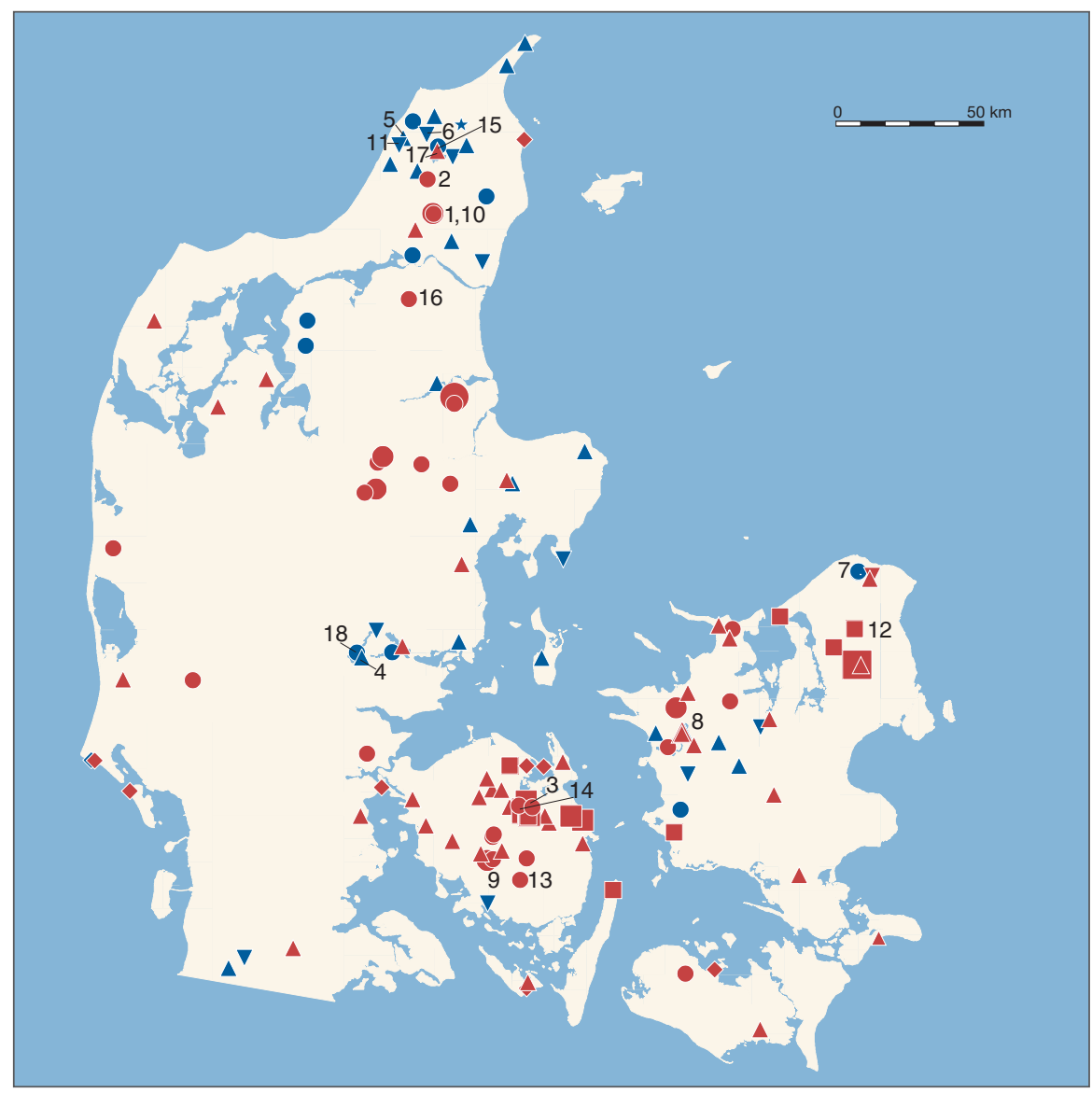

Fig. 2. Udbredelseskortet viser fordelingen af 139 lokaliteter med hjortetaksøkser fra bronzealderen i Danmark, som samlet omfatter 155 genstande. Størrelsen på punkterne angiver, om der er fundet én, to eller tre hjortetaksøkser. Cirkel: å- og søfund. Trekant (spids op): mose- og vådområde. Firkant: bosættelse. Rhombe: strand, hav, fjord. Stjerne: gravhøj. Trekant (spids ned): ukendt. Røde punkter er hentet fra registreringer i Fund og Fortidsminder: http://www.kulturarv.dk/fundogfortidsminder/, mens de blå er afsat ved hjælp af kort og stednavne. Numrene angiver de lokaliteter, hvor der er foretaget C14-dateringer. På nogle af lokaliteterne er der dateret to økser fra samme lokalitet, hvilket gælder numrene: 7, 8, 9 og 10. Samme numre indgår på fig. 15, der samtidig er en dateringsoversigt. Bornholm er udeladt, da der ikke er registreret eksempler på hjortetaksøkser her. - Kort: Lise Frost.

Distribution map showing the 139 locations for finds of a total of 155 antler axes from the Danish Bronze Age. The size of the dots denotes the number of antler axes found at each locality (one, two or three). Circle: river/lake. Standing triangle: meadow/bog. Square: settlement. Rhombus: sea/shore/fjord. Star: burial mound. Hanging triangle: unknown. Red dots mark an exact location with reference to the Danish national Sites and Monuments database (http://www.kulturarv.dk/fundogfortidsminder/). Blue dots mark more approximate locations and refer to place names and/or land register numbers. The numbers relate to locations where antler axes have been ${ }^{14} \mathrm{C}$ dated. Two axes have been dated at some locations: 7, 8, 9 and 10 (also presented in fig. 15). No finds of Bronze Age antler axes have been recorded on Bornholm and the island has therefore been omitted from this map. 


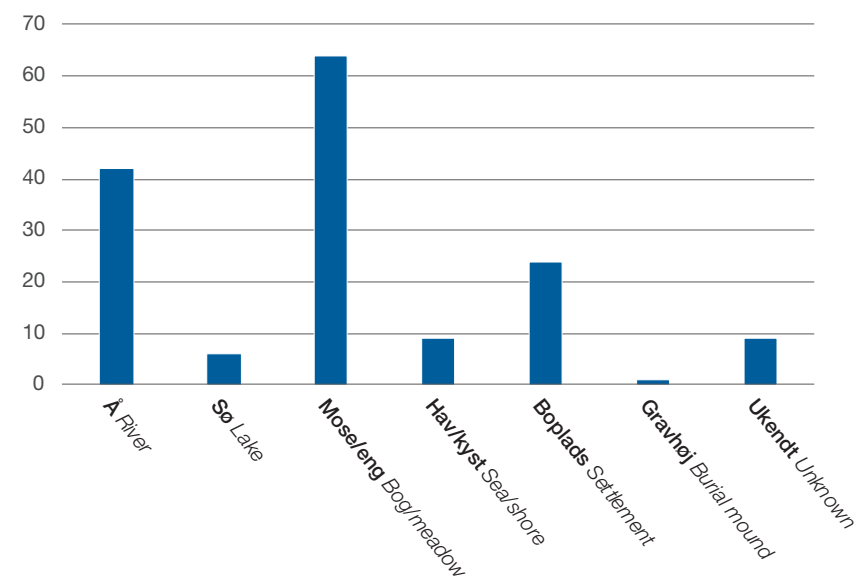

Fig. 3. Tabel med fundforholdene for de 155 hjortetaksøkser, hvor hovedparten er knyttet til vand og vådområder.

The contexts for the 155 axes. The majority were associated with water and bog/meadow areas.

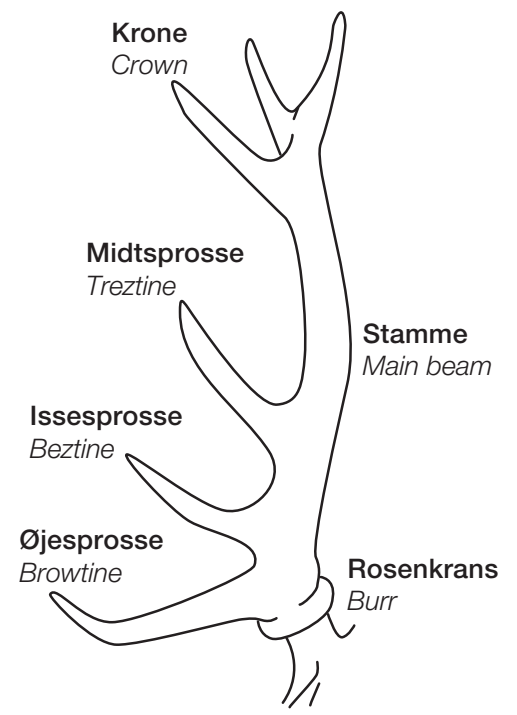

Fig. 4. Tegning over gevirets dele, hvor bronzealderens hjortetaksøkser primært er udformet i området omkring rosenkransen og med skafthullet igennem øjesprossen.

- Efter Ulbricht 1978, 18, Abb. 2 og Kveiborg 2011, fig. 3.

The various parts of a red deer antler. Most of the Bronze Age antler axes were made from the part around the burr, with the shaft-hole being made through the brow tine. 


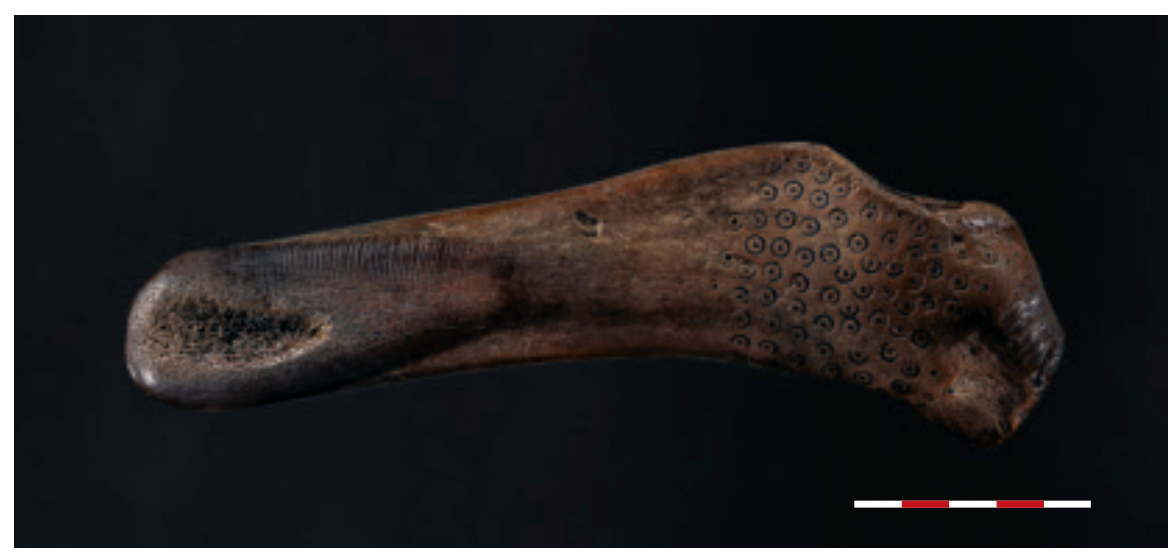

Fig. 5. Hjortetaksøkse med punktcirkelornamentik fra Jorløse Mose i Vestsjælland. Skafthullet sidder langt tilbage, og øksen har den karakteristiske nedadbøjede nakke. Øksen er ${ }^{14} \mathrm{C}$-dateret til yngre bronzealder $\left(2885 \pm 26{ }^{14} \mathrm{C}\right.$ år bp, fig. 15 nr. 8 _ $)$. - Foto: Foto/Medie Moesgaard, Michael Johansen.

Antler axe with point-circle ornamentation from Jorløse Mose, western Zealand. The shaft-hole is located at the rear of the axe, which has the characteristic down-turned butt. The axe has been ${ }^{14} \mathrm{C}$ dated to the Late Bronze Age (2885 $\pm 26{ }^{14} \mathrm{C}$ years bp, fig. 15 no. $\left.8 \_1\right)$.

skæftet som retøkser (se f.eks. fig. 5, 9, 12 og 21). Til gruppen knytter sig også et fåtal af de såkaldte T-økser, hvis form kendes fra yngre Ertebøllekultur (fig. 4).

I få tilfælde foreligger der efterretninger om rester af et isiddende træskaft, men ellers er det alene øksehovederne, som er bevaret helt eller delvist. Udbredelseskortet omfatter også en lille håndfuld økseskafter i hjortetak, som tilhører samme genstandsgruppe og har ens ornamentik. ${ }^{14}$

Hjortetaksøkser fra bronzealderen har typisk en mere eller mindre nedadbøjet nakke, hvilket bl.a. hænger sammen med, at skafthullerne er udformet igennem øjesprossen og dermed går igennem et tykkere stykke gevir, samt at de typisk er trukket længere bagud end på de mesolitiske økser (fig. 5).

Råmaterialet til økserne kan være gevir, der enten er skaffet til veje i forbindelse med jagt på kronhjort eller ved indsamling af de såkaldte kastestænger, men ud fra øksematerialet er det umiddelbart vanskeligt at afgøre, hvad der var det mest almindelige. I begge tilfælde kræves, at nakkeområdet fremstår mere eller mindre ubearbejdet, og det er typisk ikke tilfældet. På godt en håndfuld af hjortetaksøkserne er rosenstokken dog bevaret som en del af øksens nedadbøjede nakke, hvilket viser, at der ikke er tale om kastestænger (fig. 6). Fund af knogler fra vildt er generelt få i bronzealderens faunamateriale, men på helleristninger forekommer indimellem jagtscener med hunde, hjorte og mennesker. ${ }^{15}$ Hvis råmaterialet til en hjortetaksøkse derimod stammer fra en kastestang, og nakken 
er forblevet ubearbejdet, vil man kunne se det på rosenkransen, som er det sted, hvor geviret naturligt løsnes hvert forår (se f.eks. fig. 21a og b). ${ }^{16}$

Nogle af hjortetaksøkserne virker mere som en art trofæer eller kultøkser end som egentlige brugsgenstande. ${ }^{17}$ Andre virker stærkt slidte, selvom de har ornamentik over hele overfladen. ${ }^{18} \mathrm{Og}$ både blandt de ornamenterede og uornamenterede er der økser, som virker ubrugte. I en generel deponeringsmæssig bronzealdersammenhæng er det typisk at se en blanding af brugte og ubrugte genstande imellem hinanden, men det er stadig uklart, hvad de slidte hjortetaksøkser har været anvendt til? Eksperimenter og analyser i forbindelse med en gruppe af de mesolitiske hjortetaksøkser har vist, at økserne primært har været anvendt ved arbejde i træ. ${ }^{19}$ Om denne brug også kan gælde for nogle af de slidte bronzealderøkser er imidlertid ikke klart og vil kræve omfattende analyser af forarbejdnings- og slidspor samt eksperimenter med moderne tak.

\section{Ornamentik}

Ornamentikken var som nævnt afgørende for, at man omkring 1900-tallet for alvor blev klar over, at nogle af disse enkeltfundne hjortetaksøkser faktisk skal dateres til bronzealderen. ${ }^{20} \mathrm{Ud}$ af det samlede antal økser på 155 stk. har 59 synlig ornamentik på overfladen. Punktcirkelornamentikken i form af en

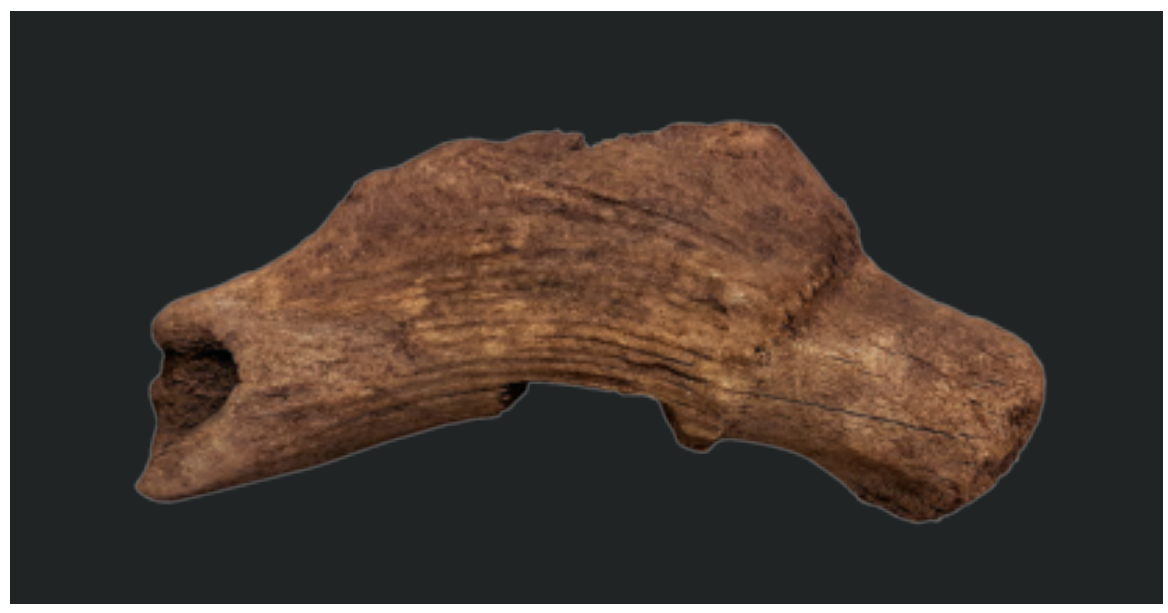

Fig. 6. Hjortetaksøkse fra en mose ved Veggerslev på Djursland, hvor rosenstokken ses som en del af den nedadbøjede nakke. Øksen måler ca. $20 \mathrm{~cm}$ i længden, hvoraf rosenstokken udgør ca. 5-6 cm. - Foto: Anna Tjelldén, Moesgaard Museum.

Antler axe found in a bog near Veggerslev, Djursland. The burr forms part of the downturned butt. The length of the axe is around $20 \mathrm{~cm}$, of which the burr makes up approximately 5-6 cm. 


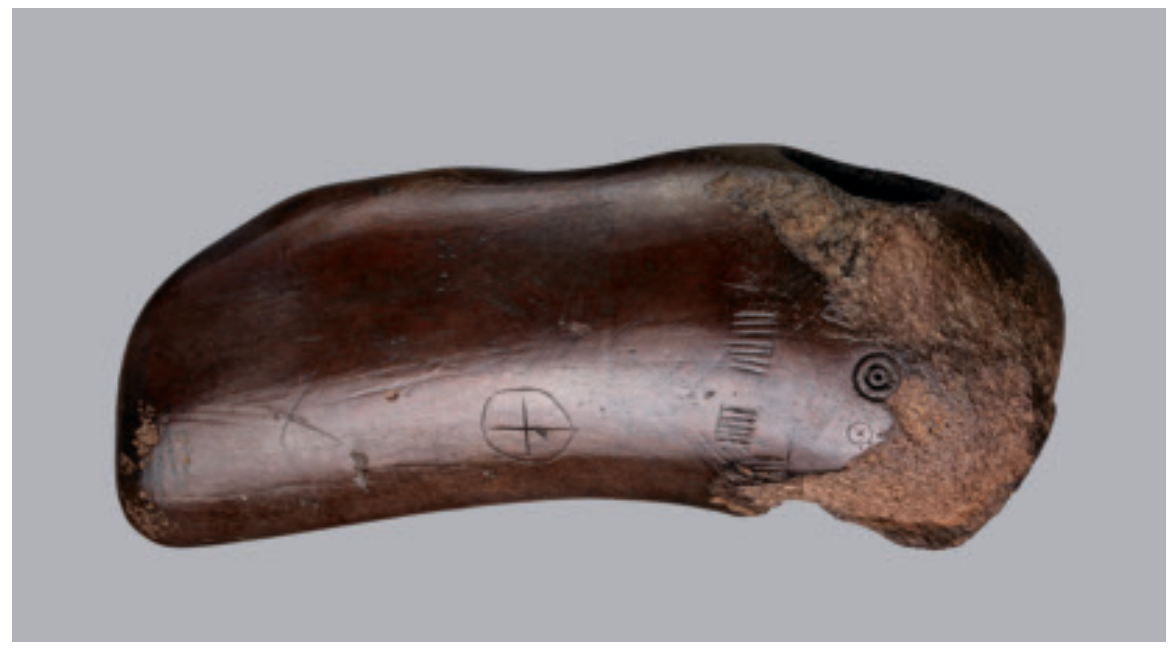

Fig. 7. Hjortetaksøkse (måler $15 \mathrm{~cm}$ i længden) med punktcirkelornamentik, stregbundter (kamornamenter?) og et karakteristisk bronzealdersymbol i form af hjulkors fra en mose ved Nørre Broby på Fyn. - Foto: John Lee, Nationalmuseet.

Antler axe with point-circle ornamentation, line clusters (comb ornamentation?) and characteristic Bronze Age symbols in the form of wheel crosses. Found in a bog near Nørre Broby, Funen.

eller flere cirkler omkring et fordybet midtpunkt er det hyppigste motiv og forekommer på 43 ud af de 59 ornamenterede eksemplarer. Der har været forskellige bud på dateringen af ornamentikelementet, som både tidsfæstet til xldre og yngre bronzealder. ${ }^{21} \mathrm{Og}$ begge dele er korrekt i den forstand, at ${ }^{14} \mathrm{C}$ dateringer foretaget som led i dette projekt har vist, at ornamentikelementet går tilbage til ældre bronzealders periode II (fig. $15 \mathrm{nr} .1 \mathrm{og}$ 2), men at det også forekommer langt op i yngre bronzealder (fig. $15 \mathrm{nr} .12 \mathrm{og}$ 13). I øvrigt er det også et hyppigt ornamentikelement i jernalderen - bl.a. på hjortetakshåndtag til knive eller syle, på kamme af hjortetak eller i andre materialer som jern, hvor ornamentikken eksempelvis findes på lanser. ${ }^{22}$ Punktcirkelornamenter kan både i ældre og yngre bronzealder forekomme over hele øksens overflade eller mere spredt, men det mest almindelige er, at ornamentikken ses omkring øksernes nakkeender, hvor den kan være afgrænset af tværgående linjebånd (se f.eks. fig. 1).

Ornamentikken kan også bestå af enkel stregornamentik, som typisk forekommer i bånd på tværs (se f.eks. fig. 18a). Endvidere findes eksempler på grubelignende neddybninger i øksens overflade, der minder om miniudgaver af helleristningernes skåltegn. ${ }^{23}$ Dertil kommer sjældne eksempler på andre, ty- 
piske bronzealdermotiver som hjulkors (se fig. 7), spiralornamenter, fletværksornamenter, vinkelbånd og kamornamentik (se fig. 8). ${ }^{24}$ Visse økser har kun én form for ornamentik som punktcirkelornamentik eller stregornamentik, men det er også almindeligt, at flere ornamentikelementer indgår på samme økse (se f.eks. fig. 7, 8 og 9).

Beg udvundet af harpiks har igennem hele oldtiden været anvendt som lim, imprægnering og indlægsmasse på forskellige genstande. På hjortetaksøkserne indgår beg typisk som en del af ornamentikken, hvor den mørke masse er indlagt i de neddybede ornamentikelementer som kontrast til øksens lysere overflade. $^{25}$

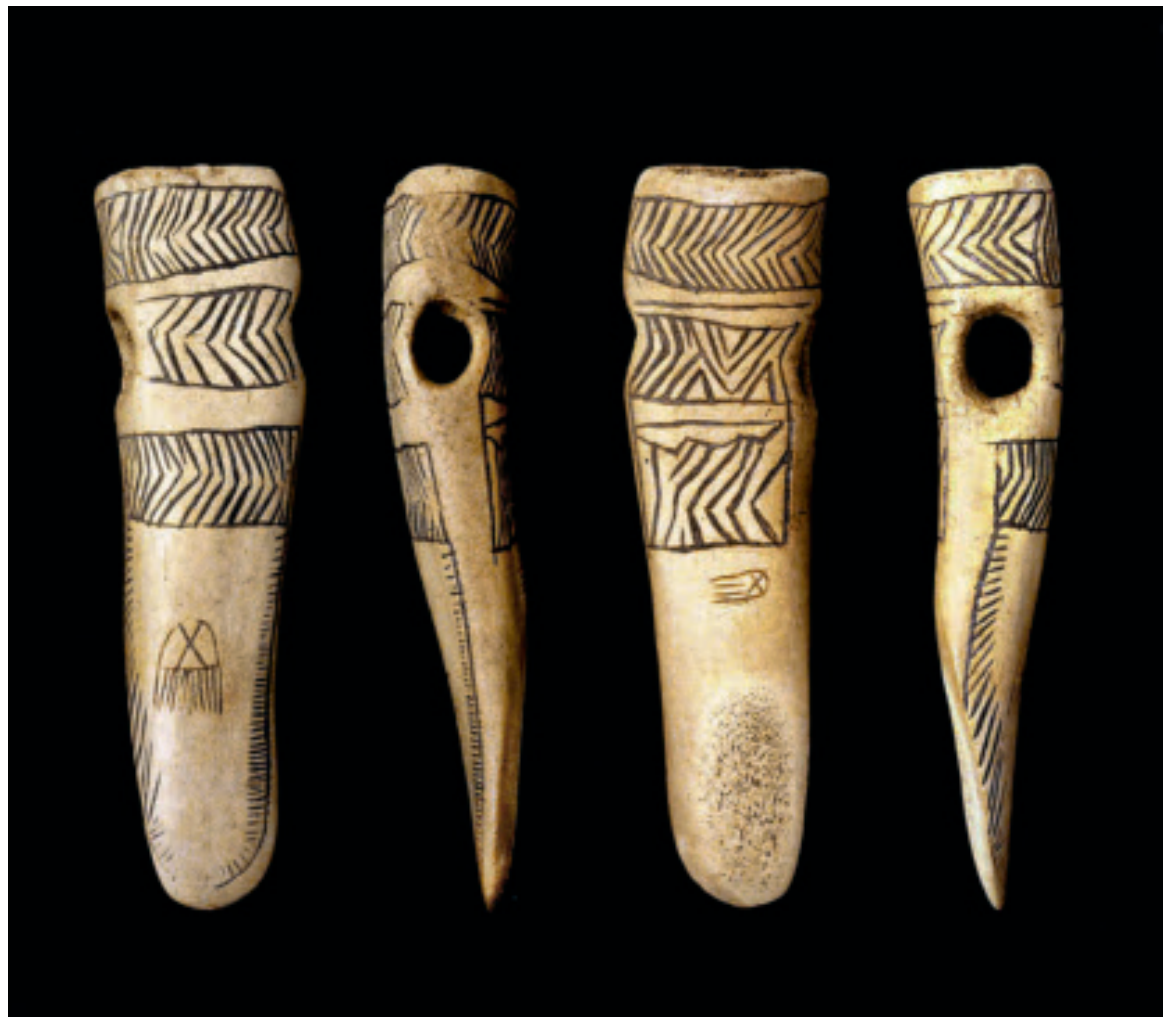

Fig. 8. Hjortetaksøkse (måler $17 \mathrm{~cm}$ i længden) med vinkelbåndsornamentik og med angivelse af en kam på begge bredsider. Fundet ved Bonderup Bro, Østeråen syd for Aalborg. $\varnothing \mathrm{ksen}$ er dateret til yngre bronzealder $\left(2559 \pm 50{ }^{14} \mathrm{C}\right.$ år bp, fig. 15 nr. 16). - Foto: Per Thorling Hadsund, Nordjyllands Historiske Museum.

Antler axe with lines and comb ornamentation on both sides. Found at Bonderup Bro, Østeråen, south of Aalborg. The axe has been ${ }^{14} \mathrm{C}$ dated to the Late Bronze Age $(2559 \pm 50$ ${ }^{14} \mathrm{C}$ years bp, fig. 15 , no. 16 ). 


\section{Analyse af metalrester på to hjortetaksøkser}

Visse ornamentikelementer hænger sammen med områder på hjortetaksøksen, hvor der oprindelig har siddet en gevirsprosse, der er blevet fjernet og derfor nogle steder har givet en spongiøs eller småhullet overflade, som man indimellem har formået at vende til noget særligt, og som ornamentikken på den ene eller anden måde orienterer sig i forhold til. Det ses f.eks. på hjortetaksøksen fra Trundholm Mose i Odsherred, hvor der er lavet et ovalt ornament rundt i kanten af den afsavede sprosse. ${ }^{26}$

\section{Hjortetaksøkse fra Jelstrup i Vendsyssel}

En unik løsning ses på en streg- og punktcirkelornamenteret hjortetaksøkse fra Jelstrup i det vestlige Vendsyssel (fig. 9; fig. 15 nr. 11). Desværre er der ikke yderligere fundoplysninger på øksen, men fjernelsen af issesprossen på gevirstykket her har efterladt et spongiøst område, som punktcirkelornamenterne med begindlægning grupperer sig udenom. Feltet måler ca. 1,5x1,5 cm og sidder tæet på skafthullet, der går igennem det område, hvor gevirets øjesprosse har siddet. I den venstre side af det uornamenterede felt ses to borehuller. I det ene sidder en lille metalstift, mens det andet borehul er tomt, men formentlig har der siddet en lignende metalstift her. I højre side af feltet ses begklatter, der i dette tilfælde nok har skullet fungere som lim (fig. 10). Metalstiften og det omgivende område er analyseret med mikro-røntgensfluorescens ( $\mu$-XRF). Analysemetoden foregår ved, at en røntgenstråle skydes mod en genstands overflade og slår elektronerne ud af grundstoffernes inderste elektronbaner.

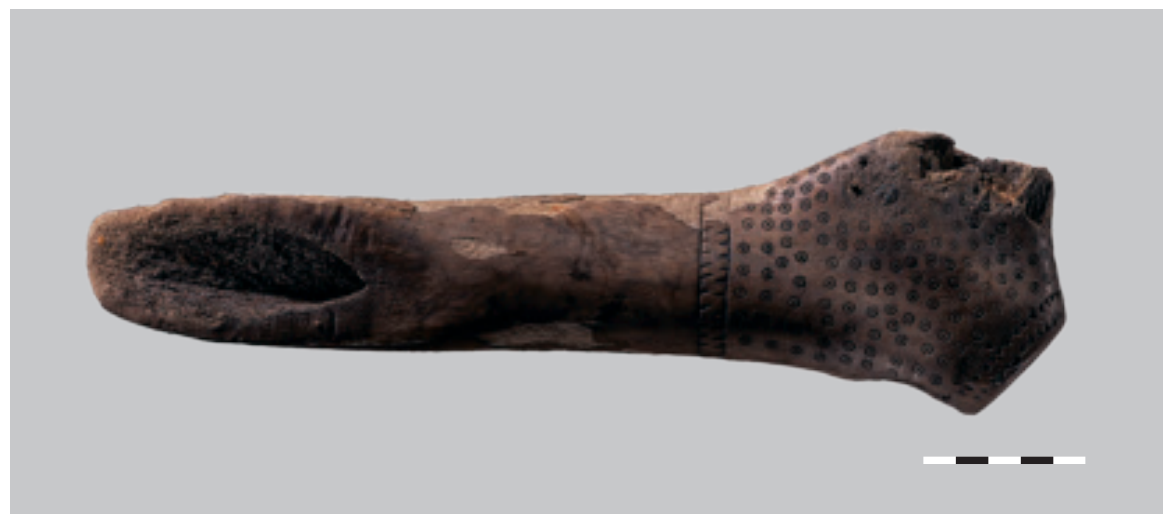

Fig. 9. Hjortetaksøkse fra Jelstrup i Vendsyssel (se også fig. 1, 10, 11 \& 15).

- Foto: Michael Johansen, Foto- og Medieafdelingen, Moesgaard Museum.

Antler axe from Jelstrup in Vendsyssel (see also figs. 1, 10-11 and 15). 


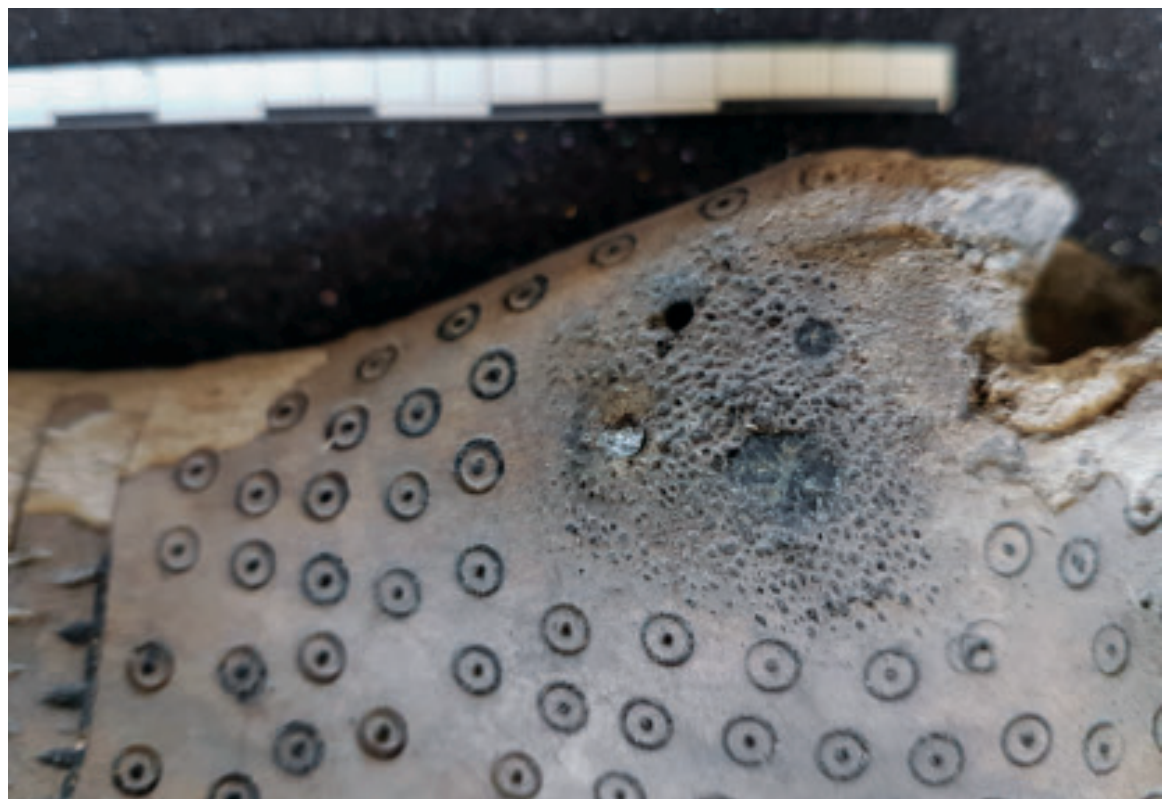

Fig. 10. Nærbillede af det spongiøse område på Jelstrupøksen med metalstift, borehul og begklatter. - Foto: Anna Tjelldén, Moesgaard Museum.

Close-up of the spongious area of the Jelstrup axe with metal pin, drilled hole and blobs of pitch.

Når disse elektroner bliver erstattet ved, at elektroner fra atomets ydre baner 'hopper' ind for at overtage den tomme plads, udsendes sekundære røntgenstråler, der karakteriserer hvert enkelt grundstof i prøven. ${ }^{27}$ Analysen er således ikke-destruktiv og efterlader ingen spor på genstanden. Derved kan man ikke blot bestemme den kemiske sammensætning af genstandens overflade, men også kortlægge områder med forskellige sammensætninger inden for det analyserede område (fig. 11).

Analyserne af både metalstiften og området rundt om den viste, at der her er tale om næsten rent tin (98,1\%). Måleresultatet peger dermed på, at der dels i metalstift(er) af tin og dels ved begklatter oprindelig har været fastgjort en form for tinlap, som har dækket det spongiøse område og fungeret som et helt særligt ornamentikelement på denne økse.

Tin indgår selvfølgelig som en komponent sammen med bl.a. kobber i bronzegenstande, og selvom stiften er ganske lille og kun stikker få millimeter op af borehullet, er det sjældent at se metallet i gedigen form. Dog er der i dansk sammenhæng få andre eksempler på små tinelementer i bronzealdergenstande. Det gæelder f.eks. tinstifter indsat som en art stjerneornamentik på 


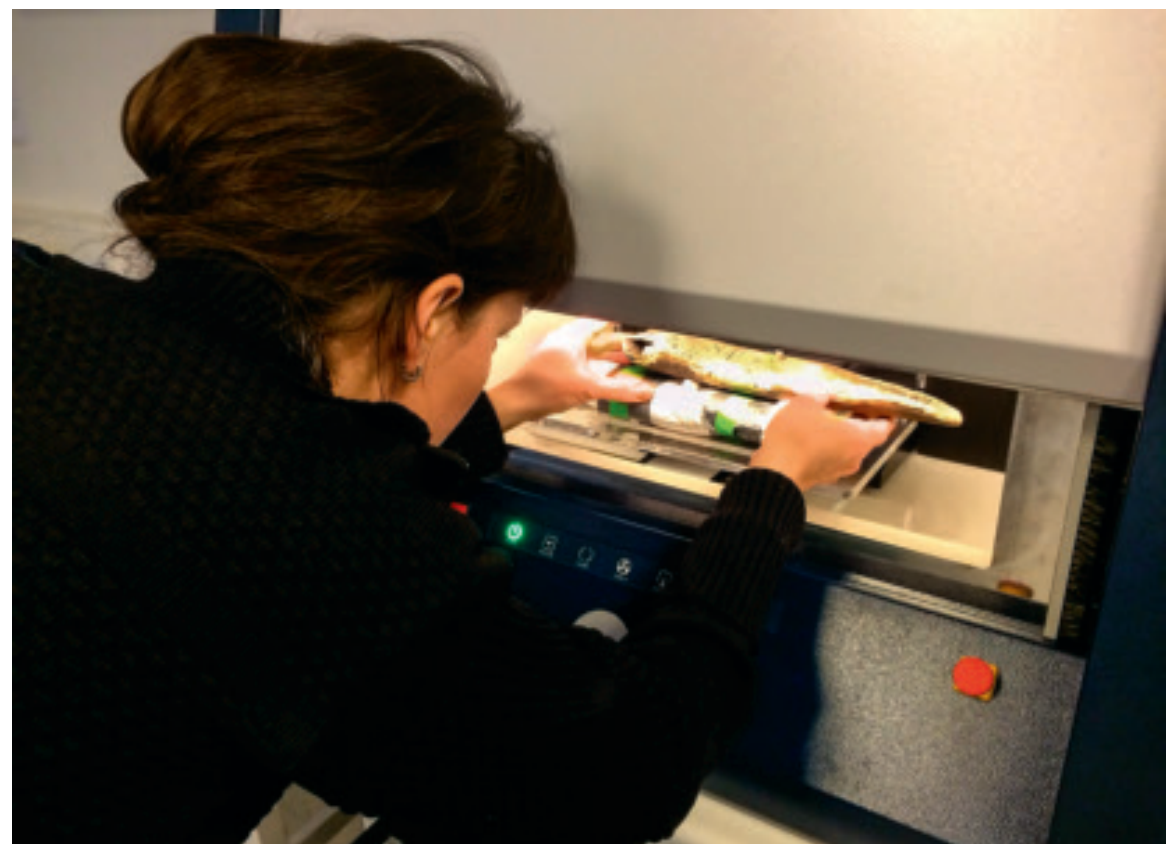

Fig. 11. Jelstrupøksen lægges til analyse i mikro-XRFéns kammer (Aarhus Geochemical and Isotope Research (AGiR) Platform). Herefter lukkes kammeret og sættes under vakuum. - Foto: Gry H. Barfod, AGiR.

The Jelstrup axe being placed in the micro-XRF chamber. After closure of the chamber a vacuum is created.

nogle af de trækar, der er fundet i egekistegrave fra ældre bronzealder. ${ }^{28}$ Tin indgår også som indlægning i ornamentikken på et mindre lerkar fra en grav ved Boeslunde, der dog formentlig er et importstykke. ${ }^{29}$

\section{Hjortetaksøkse fra Boring Mark ved Horsens}

Der er foretaget metalanalyse i forbindelse med endnu en hjortetaksøkse (fig. 12). Her er situationen anderledes, idet metallet på denne økse kunne anes som en svagt grøn, irret overflade i forbindelse med noget af punktcirkelornamentikken (fig. 13). Her er ligeledes foretaget mikro-røntgensfluorescens ( $\mu$-XRF), som i dette tilfælde klart indikerer, at der har været indstukket små bronzestifter i beget i forbindelse med punktcirkelornamentikken. Her har bronzeudsmykningen givet en flot kontrastvirkning med det mørke beg og det gyldne metal på den hvidgule hjortetaksøkse. Analyserne viser, at metallet er bedst bevaret i centrum, mens den omgivende bronze er irret, har mistet tin og optaget jern-oxid fra grundvand i løbet af de århundreder, som øksen har ligget i jorden (fig. 14). 


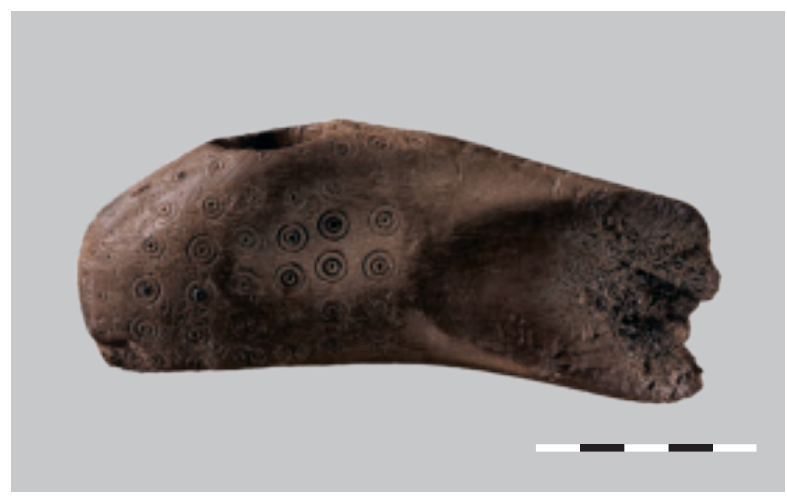

Fig. 12. Hjortetaksøkse fra Boring Mark ved Gudenåen vest for Horsens (se også fig. 1, 13 \& 15). - Foto: Foto/Medie Moesgaard, Michael Johansen.

Antler axe found at Boring Mark near the Gudenå river, Horsens.

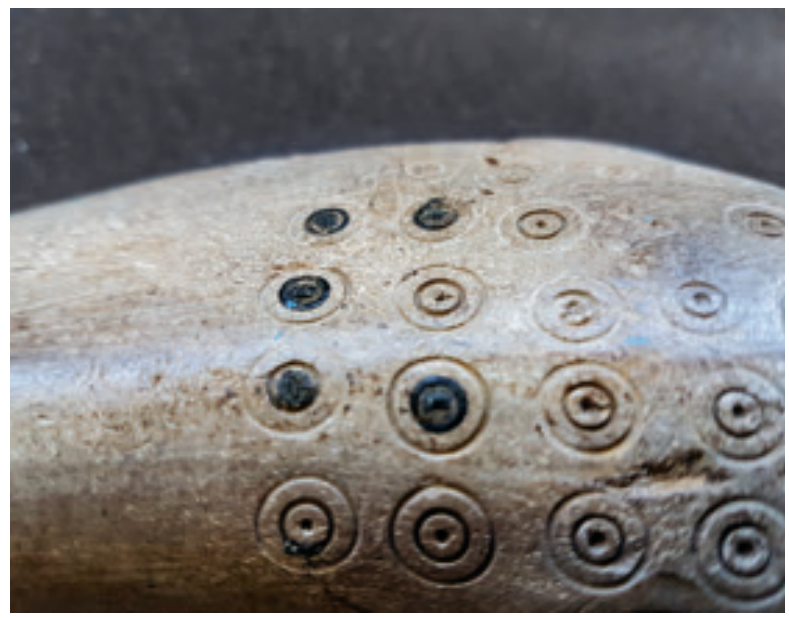

Fig. 13. Nærbillede af noget af punktcirkelornamentikken på øksen fra Boring Mark, hvor rester af bronze ses som grønirret farvning i forbindelse med punktcirkelornamentikken. - Foto: Anna Tjelldén, Moesgaard Museum.

Close-up of the pointcircle ornamentation on the axe from Boring Mark where slight green metal traces (bronze remains) are evident in some cases.

Metalelementer i sammenhæng med hjortetaksøkser har ikke kunnet erkendes på andre af de 155 indsamlede eksemplarer, men det har været muligt at finde et par tyske eksempler på, at metalstifter af forskellig art kan indgå i forbindelse med hjortetaksøksernes ornamentik. ${ }^{30}$

I forlængelse af gennemgangen af karakteristika ved hjortetaksøkserne fra bronzealderen vil resultater af ${ }^{14} \mathrm{C}$-dateringer nedenfor blive inddraget.

\section{Hjortetaksøksernes kronologiske ramme}

Hidtil har der været publiceret et par enkelte dateringer af hjortetaksøkser, som begge ligger i yngre bronzealder. ${ }^{31}$ Det samme viser fundkonteksten for de hjortetaksøkser, som er fundet i gruber i relation til bosættelser. Det har dog ikke været afklaret, om alle hjortetaksøkser hører til i periodens yngre del, en bestemt del heraf, eller om dateringerne ligger mere spredt igennem 

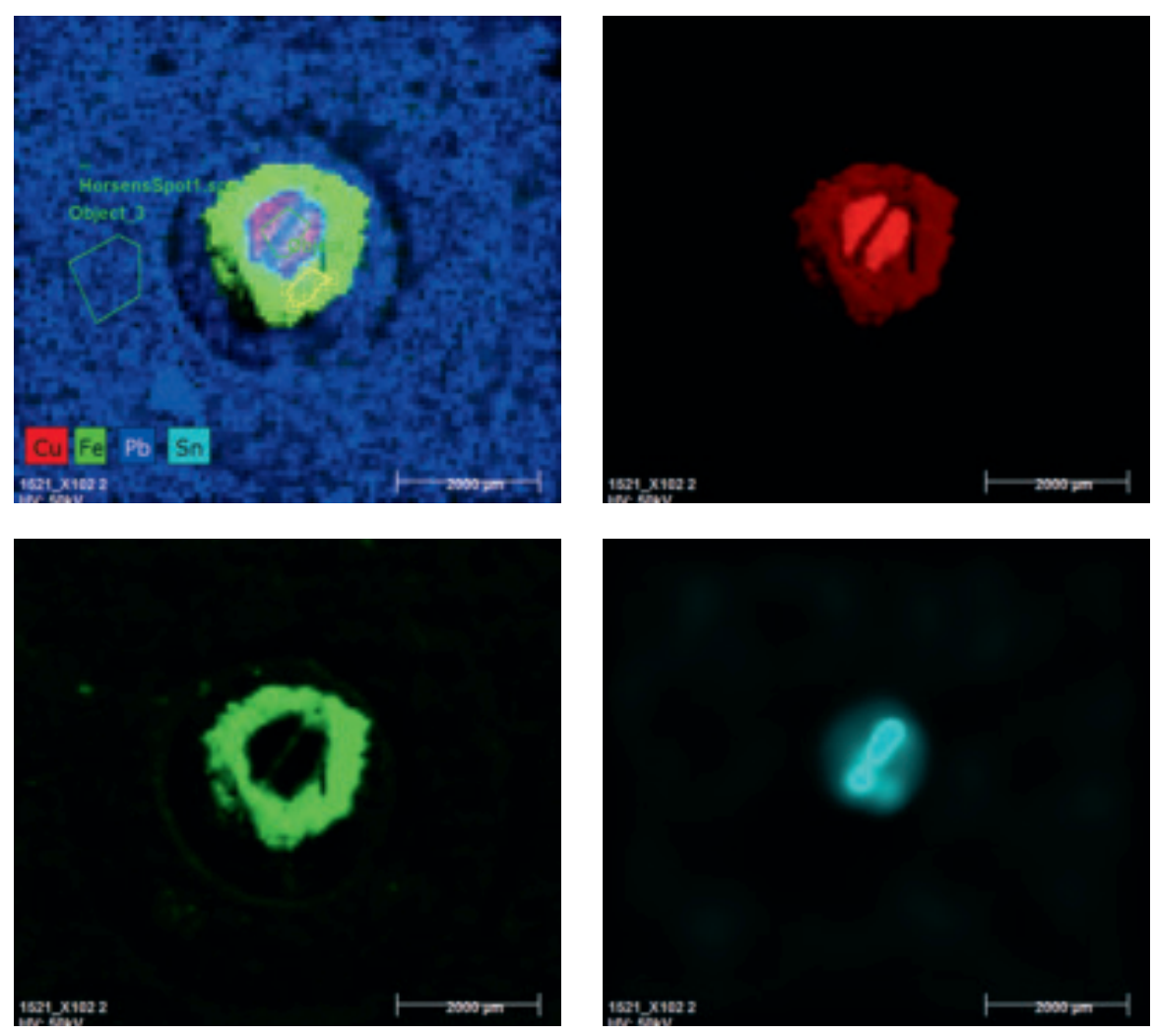

Fig. 14. Grundstofkort, som viser fordelingen af kobber (rød - øverst th), jern (grøn nederst tv) og tin (blå - nederst th) i et af punktcirkelornamenterne på øksen fra Boring Mark. Bronzen er bedst bevaret i centrum, mens kobberet i bronzen i den ydre cirkel er stærkt irret, har mistet tin og i stedet optaget jern-oxider fra grundvand. - Analyse og foto: Gry H. Barfod, AGiR.

Element map showing the distribution of copper (red - top right), iron (green - bottom left) and tin (blue - bottom right) in one of the point-circle ornaments on the axe from Boring Mark. The best preservation of bronze is seen in the centre, while the copper in the bronze in the outer circle is very corroded, has lost tin and has absorbed iron oxides from groundwater.

hele bronzealderen. Nye ${ }^{14} \mathrm{C}$-dateringer er derfor et afgørende element. Der er i alt udtaget 20 prøver til datering, hvoraf én desværre måtte udgå, da prøven viste sig at være uegnet på grund af konserveringsvæske. Som det fremgår af figur 15, præsenteres her 19 nye ${ }^{14} \mathrm{C}$-dateringer sammen med yderligere tre dateringsresultater, der er foretaget forud for projektet. ${ }^{32}$ De 19 nye dateringer er alle foretaget på ekstraheret kollagen. ${ }^{33}$

Dateringsresultaterne viser, at hjortetaksøkser fra forskellige egne af landet i varierede fundkontekster og med forskelligt udseende (poleret/upoleret 
1. Kraghede, Ryå AAR-28283 $(3115,29)$

2. Kalum Bæk AAR-27672 $(3078,30)$

3. Odense Å AAR-28140 $(3024,27)$

4. Boring Mark AAR-27677 $(3006,28)$

5. Rubæk AAR-27671 $(2982,31)$

6. Hjørring AAR-27676 (2944,32)

7_1. Søborg Sø AAR-28284 $(3115,24)$

8_1. Jorløse Mose AAR-28142 $(2885,26)$

9_1. Sønder Broby, Odense Å AAR-28138 $(2878,26)$

10_1. Hvilshøjgård, Ryå AAR-28286 $(2871,29)$

11. Jelstrup AAR-27674 $(2854,29)$

8_2. Jorløse Mose AAR-28143 $(2797,28)$

10_2. Hvilshøjgård, Ryå AAR-28287 $(2752,21)$

12. Solrødgård* POZ-80357 $(2730,30)$

13. Åmarkgård* AAR-8316 $(2680,30)$

14. Vejrup $\AA$ AAR-28141 $(2611,24)$

9_2. Sønder Broby, Odense Å AAR-28139 $(2598,25)$

15. Ilbro, Uggerby Å AAR-27673 $(2579,28)$

16. Bonderup Bro* AAR-7904 $(2559,50)$

17. Sønderbroens Enge AAR-27675 $(2514,24)$

18. Bygholm Å AAR-27678 $(2513,26)$

7_2. Søborg Sø AAR-28285 $(2488,24)$
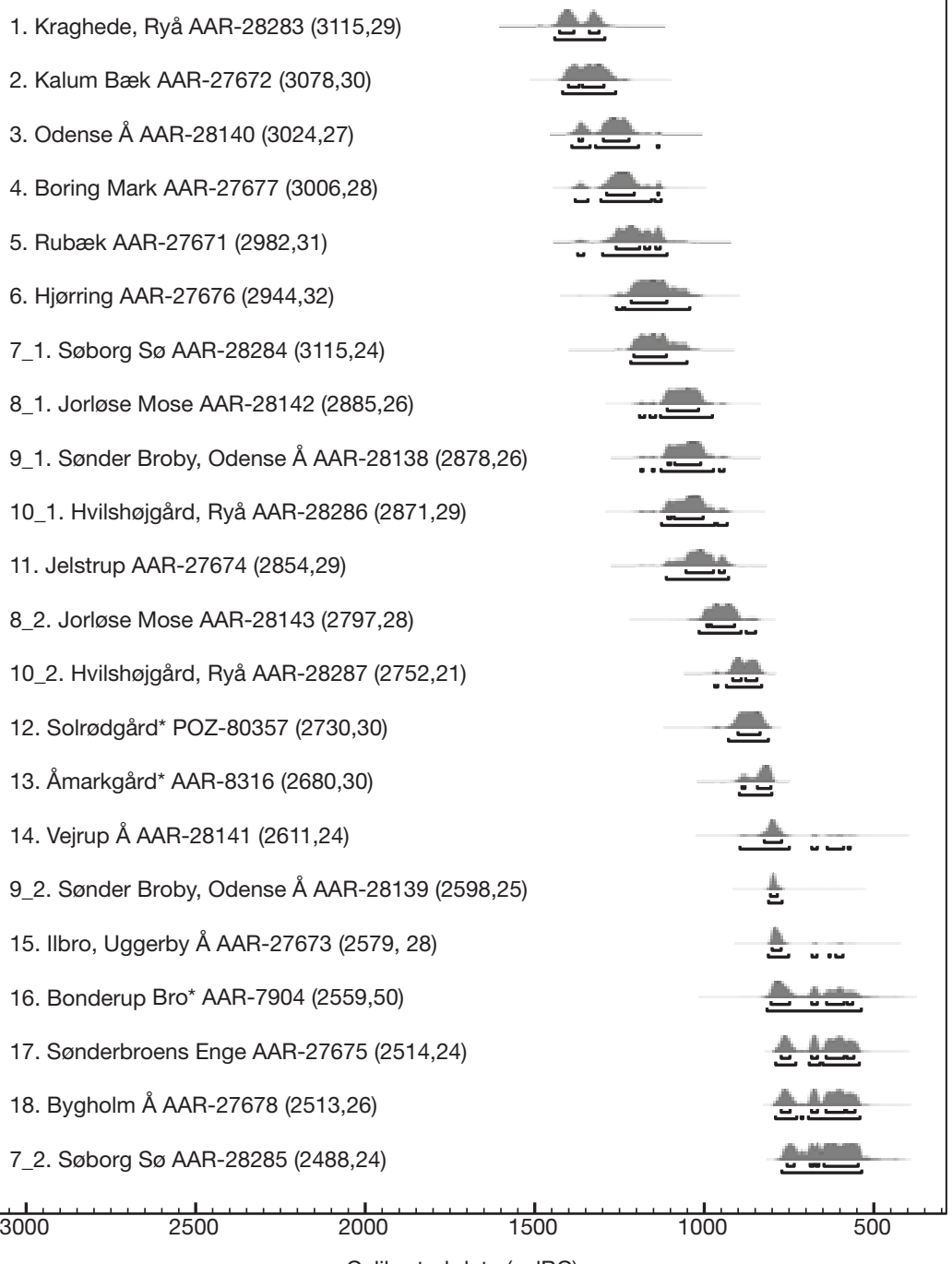

Calibrated date (calBC)

Fig. 15. Præsentation af de 19 nye C14-dateringer samt yderligere tre (markeret med stjerne) C14-dateringer udført forud for dette projekt. Numrene ved lokalitetsnavne er også angivet på kortet (fig. 2) og giver herved en geografisk oversigt over, hvor der er foretaget dateringer, og undernumre angiver, at der er foretaget datering af to økser fra samme lokalitet $(7,8,9$ og 10). Den målte alder $\mathrm{i}^{14} \mathrm{C}$-år $\mathrm{bp} \pm 1 \sigma$ er angivet i parentes. Kalibrering er foretaget ved brug af kalibreringsprogrammet OxCal v4.3.2 Bronk Ramsey 2017 (Bronk Ramsey 2009); r:5; samt den atmosfreriske kalibreringskurve IntCal13 (Reimer et al 2013). - Grafik: Marie Kanstrup.

The 19 new ${ }^{14} \mathrm{C}$ dates obtained during the project together with three dates (marked with a star) obtained previously. The numbers by the site location names are also presented on the map (fig. 2) and provide a geographical overview of where the ${ }^{14} \mathrm{C}$ dates were obtained. In some cases, two axes found at the same location have been dated $(7,8,9$ and 10$) \cdot{ }^{14} \mathrm{C}$ years $\mathrm{bp} \pm 1 \sigma$ given in brackets. Calibration: OxCal v4.3.2 Bronk Ramsey 2017 (Bronk Ramsey 2009); r:5; and IntCal13 (Reimer et al 2013). 
overflade, rundt/firkantet skafthul, ornamenteret/uornamenteret) er et ret gennemgående fænomen i både ældre og yngre bronzealder. Det gælder således både i forhold til de punktcirkelornamenterede stykker, som forekommer fra ca. midten af ældre bronzealder og frem til omkring 800 f.Kr. (fig. $15 \mathrm{nr}$. 1, 2, 4, 8, 11, 12 og 13) og de upolerede typer med firkantet skafthul, der både optræder sent i ældre bronzealder og tilsyneladende bliver mere enerådende i den yngre del af perioden (fig. 15 nr. 7_1, 15, 17, 18 og 7_2).

Prøvemængden til ${ }^{14} \mathrm{C}$-datering er stærkt knyttet til bevaringstilstanden for det pågældende materiale, men der kræves i udgangspunktet 200-800 mg prøvemateriale til en AMS-datering af tak eller knogle. Hjortetaksøksen fra Solrødgård er som den eneste på fig. 15 dateret på grundlag af beg indlagt $\mathrm{i}$ ornamentikken, da den ikke var mulig at datere på en udtaget takprøve. ${ }^{34}$ Der er således på den ene side et behov for at få nok materiale, og på den anden side er der af æstetiske og udstillingsmæssige årsager et stort behov for at tage vare på genstandens udtryk og bevaring. Målet var derfor at sikre brugbart dateringsmateriale med færrest mulige borehuller. En sådan prøveudtagning skal være fra et sted, hvor geviret er kompakt, hvor der ikke gøres skade på

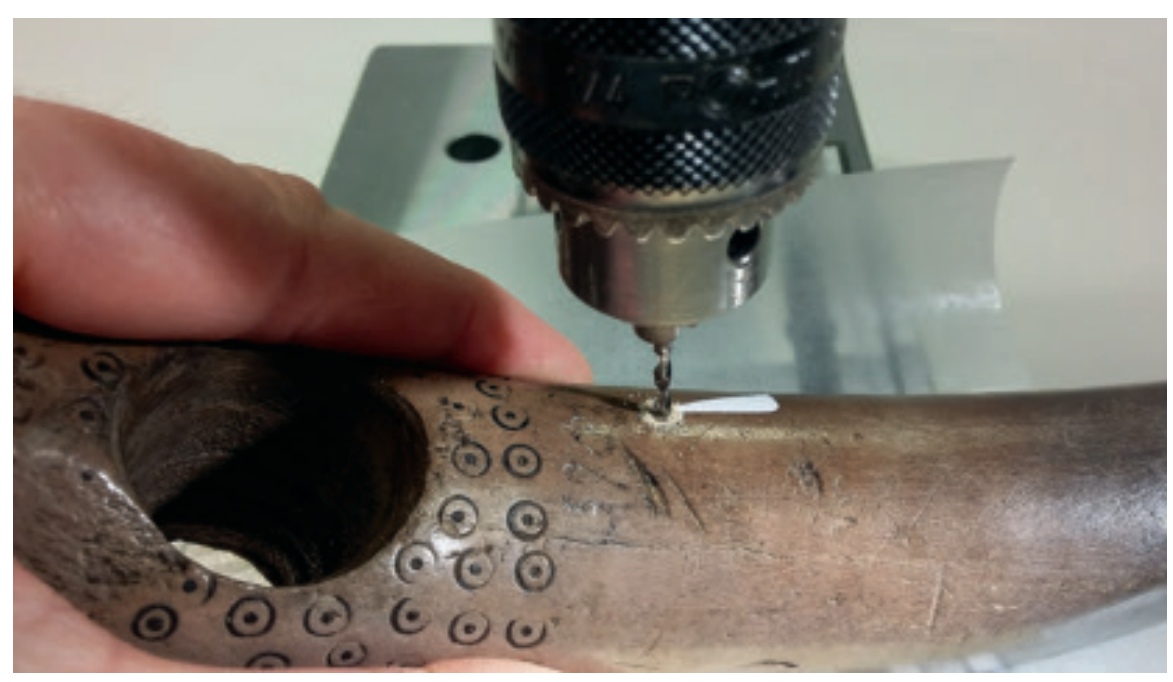

Fig. 16. På Aarhus AMS Center ved Aarhus Universitet udbores en prøve fra øksens underside tæt ved museumsnummeret til EA-IRMS-analyse med henblik på vurdering af bevaringstilstand og materialebehov til ${ }^{14} \mathrm{C}$-analyse. - Foto: Hanne Jakobsen, Aarhus AMS Center.

A sample for EA-IRMS analysis is drilled from an antler axe at the Aarhus AMS Centre, Aarhus University to assess its preservation condition. 
ornamentik og/eller forarbejdningsspor, og hvor prøvehuller er mindst muligt synlige i en udstillingssammenhæng.

I samarbejde med Aarhus AMS Center på Aarhus Universitet og konservatorer på henholdsvis Moesgaard Museum og Nationalmuseet er prøverne derfor udtaget ad to omgange. Først er der fundet og markeret et egnet sted til prøvetagning på øksens overflade, dernæst er der udboret en ganske lille prøvemængde på 5-20 mg tak (fig. 16). Ved at foretage en isotopbestemmelse af kulstof og kvælstof via en såkaldt EA-IRMS-analyse ${ }^{35}$ er det herefter muligt ud fra koncentrationerne af kulstof og kvælstof at vurdere prøvematerialets bevaringsgrad. Det sker ved at sammenligne koncentrationerne med nogle af de standarder og baggrundsprøver, som rutinemæssigt anvendes, når der foretages dateringer af knoglemateriale ved Aarhus AMS Center. ${ }^{36}$ I alle tilfælde viste den indledende test således at være godt givet ud, idet bevaringstilstanden for alle de udvalgte økser var så tilpas god, at det var tilstrækkeligt at udtage 100 $\mathrm{mg}$ tak i stedet for de $200-800 \mathrm{mg}$, der normalt udbores til en ${ }^{14} \mathrm{C}$-datering. Metoden må derfor anbefales til datering af genstande af knogle og tak, hvor der skal tages lignende æstetiske og bevaringsmæssige hensyn til genstandene - også selvom det er en mere tidskrævende dateringsproces.

\section{Datering til påvisning af enkeltdeponeringer - tids- og landskabsmæssige faktorer}

Som tidligere nævnt har hjortetaksøkser typisk været nedlagt som enkeltdeponeringer - og der er ikke fundet eksempler på, at de indgår i flertypedeponeringer. Derimod kendes eksempler på, at hjortetaksøkser er fundet på samme sted og er registreret sammen i databasen Fund og Fortidsminder. ${ }^{37}$ Derfor er det interessant at få afklaret, om de også dateringsmæssigt ser ud til at have været nedlagt på samme tid.

I bronzealderen kan bronzeøkser indgå som dele i større metaldepoter, ${ }^{38} \mathrm{men}$ det er også et karakteristisk træk, at forskellige øksetyper som randlisteøkser, celte mv. igennem hele perioden - og på linje med den øvrige, store gruppe af enkeltdeponerede genstande som halsringe, sværd mv. - er blevet nedlagt enkeltvist forskellige steder i landskabet. ${ }^{39}$ Indimellem er man flere gange vendt tilbage til de samme, afgrænsede områder, en å eller et moseområde, og nogle gange har det været med flere hundrede års mellemrum, hvilket betyder, at det $\mathrm{ud}$ fra det registrerede er vanskeligt at tale om en egentlig kontinuitet $\mathrm{i}$ deponeringerne. Derfor er det også væsentligt at inddrage landskaberne, der eksempelvis i form af et større moseområde eller et dalstrøg kan udvise en særdeles lang tidsmæssig dybde i forhold til landskabsbrug i deponeringsmæs- 
Fig. 17a og b. To hjortetaksøkser fundet sammen i forbindelse med oprensning af en strækning af Odense Å ved Sønder Broby. Dateringsmæssigt ligger de to økser imidlertid så langt fra hinanden i tid, at der formodentlig er tale om to separate nedlæggelser (17a: $2878 \pm 26{ }^{14} \mathrm{C}$ år bp og 17b: $2598 \pm 25{ }^{14} \mathrm{C}$ år bp, se Fig. 15, nr. 9_1 og 9_2). - Foto: Foto/Medie Moesgaard, Michael Johansen.

Two antler axes found together in sediment dug up during the dredging of Odense Å near Sønder Broby. The ${ }^{14} \mathrm{C}$ dates for the two axes lie very far apart, indicating that they represent two separate acts (17a: $2878 \pm 26{ }^{14} \mathrm{C}$ years bp and 17b: $2598 \pm 25{ }^{14} \mathrm{C}$ years bp, see fig. 15 , nos. 9_1 and 9_2).
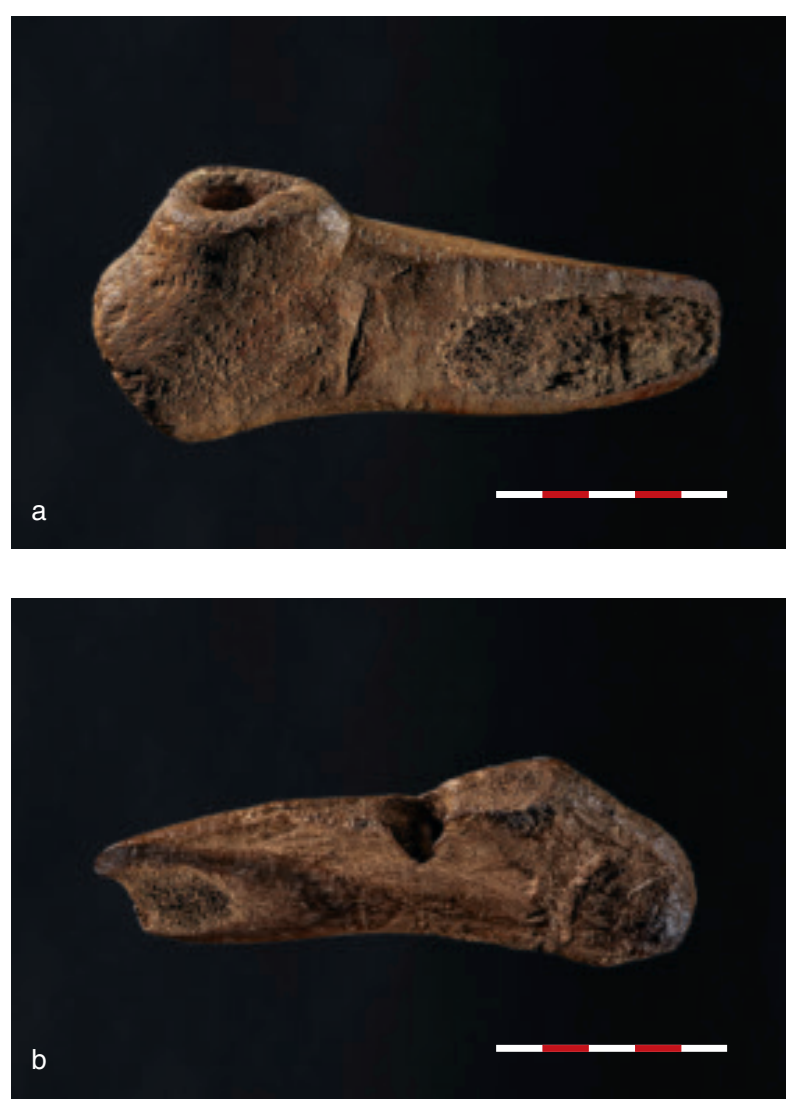

sige sammenhænge. ${ }^{40}$ Som eksempler inddrages nedenfor forskellige lokaliteter med dateringer af hjortetaksøkser, der er fundet sammen eller inden for afgrænsede områder: Odense Å ved Sønder Broby, Ryå i Vendsyssel, Jorløse Mose i Vestsjælland og Søborg Sø i Nordsjælland.

Efter rensning af en strækning af Odense Å ved Sønder Broby i 1960 var der et par drenge, som fandt to hjortetaksøkser liggende sammen på bredden i det opgravede sediment (fig. 2; fig. 15 nr. 9_1 og 9_2). De to økser er begge ret små og begge har rundt skafthul, men de ligner ellers ikke hinanden, da den ene er poleret og har et kort skaftrør i forlængelse af skafthullet, mens den anden er upoleret (fig. 17a og b). Selvom fundsituationen kan pege på et samlet fund, ligger dateringerne langt fra hinanden i tid, hvilket taler imod en samlet nedlæggelse. De to økser må derfor snarere opfattes som udtryk for to separate hændelser fra den samme strækning af åen.

Noget tilsvarende er tilfældet i Vendsyssel, hvor rensning af en strækning af Ryå ved Hvilshøjgård i 1982 førte til fundet af to hjortetaksøkser, som duk- 
kede op sammen i det opgravede sediment på bredden og blev opfattet som en entypedeponering. Begge økser har den karakteristiske, nedadbøjede nakke, men ellers er den typologiske lighed ikke stor. Dateringsmæssigt ligger de endvidere langt fra hinanden, og med mindre den ene hjortetaksøkse havde en betydelig alder ved en samlet nedlæggelse af de to, tyder det på, at der er tale om to separate deponeringshændelser (fig. 2; fig. 15 nr. 10_1 og nr. 10_2; fig. 18a og b). Tolkningen underbygges af, at der omkring 250 meter fra de
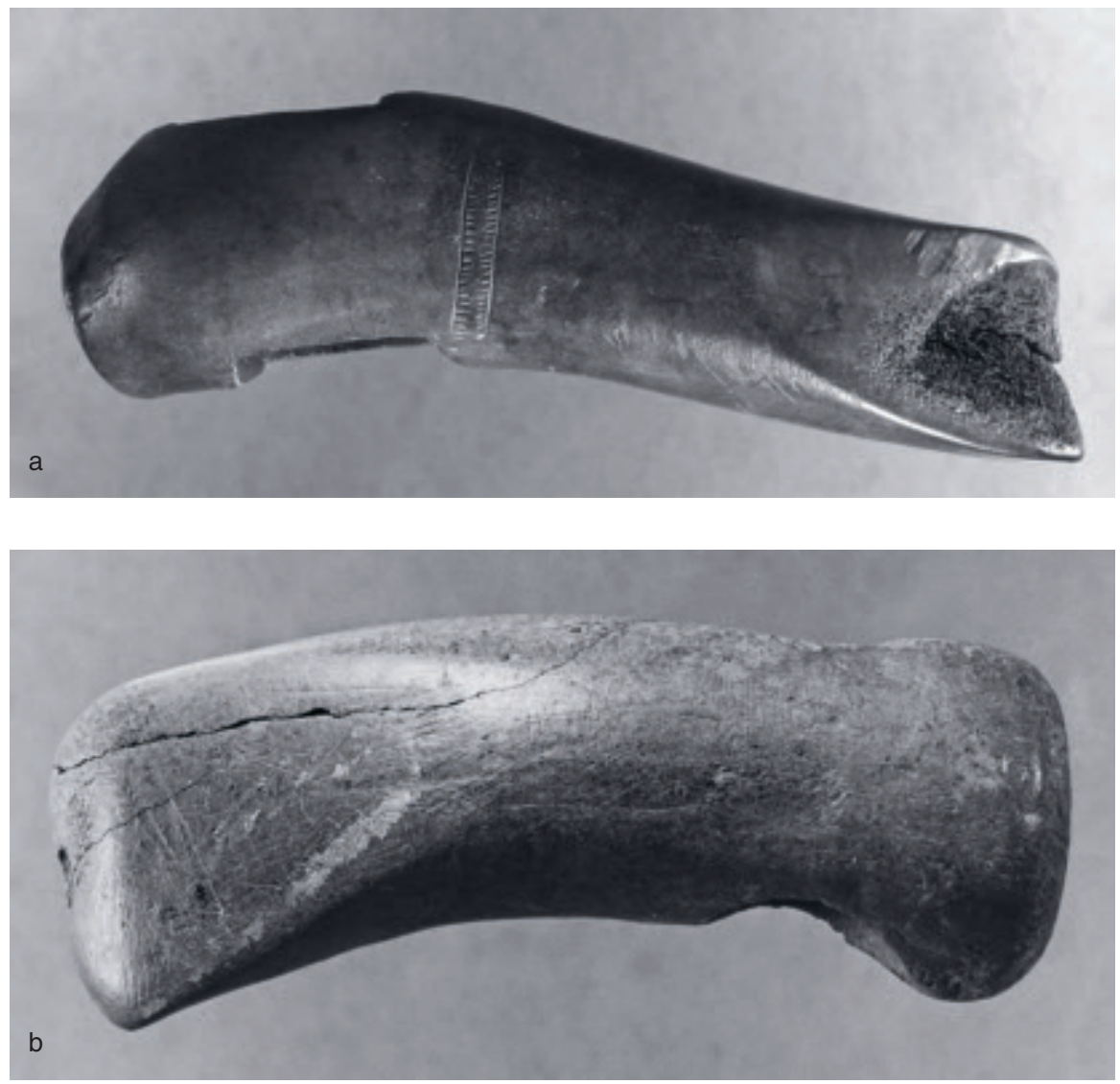

Fig. 18a og b. Omkring 250 meter fra hjortetaksøksen fra Kraghede er der ved Hvilshøjgård ligeledes i Ryå fundet to hjortetaksøkser i opgravet sediment fra rensning af en strækning af åen (19a: $2871 \pm 29{ }^{14} \mathrm{C}$ år bp, 19b: $2752 \pm 21{ }^{14} \mathrm{C}$ år bp). - Foto: Vendsyssel Historiske Museum.

Two other axes were found in sediment resulting from the dredging of a stretch of Ryå at Hvilshøjgård, about $250 \mathrm{~m}$ from the antler axe found at Kraghede (19a: $2871 \pm 29{ }^{14} \mathrm{C}$ years bp, 19b: $2752 \pm 21{ }^{14} \mathrm{C}$ years bp). 


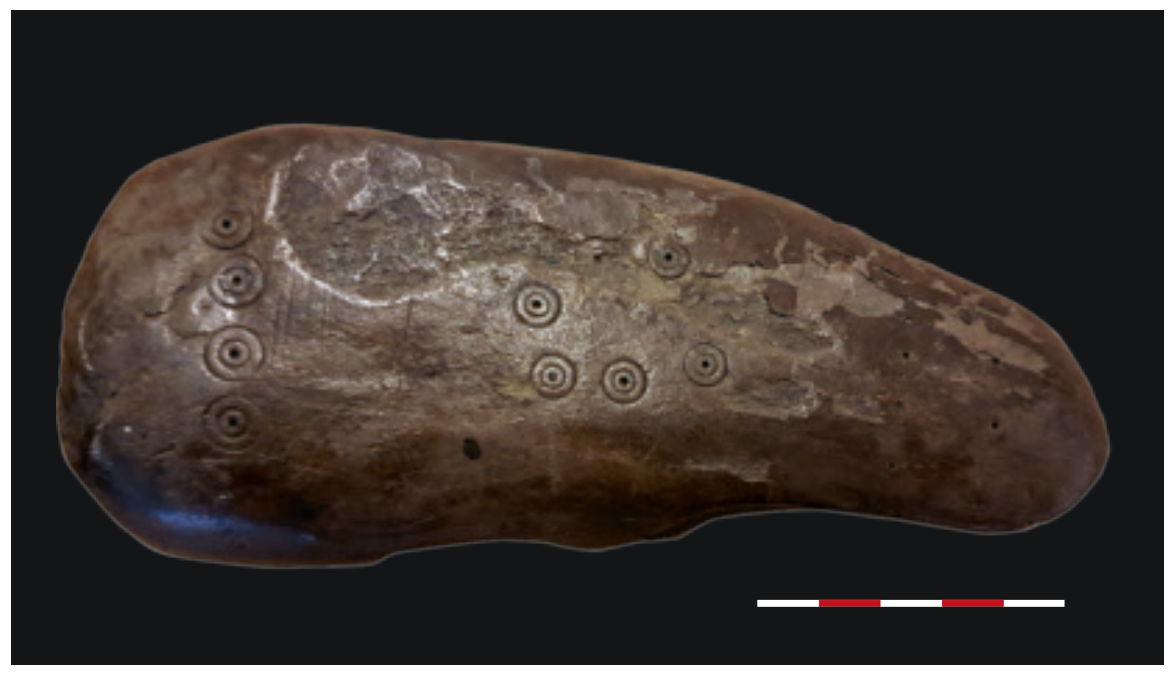

Fig. 19. Hjortetaksøkse fra Ryå ved Kraghede i Vendsyssel. Den kom for dagen i et fiskegarn og repræsenterer den ældste daterede hjortetaksøkse i undersøgelsen $\left(3115 \pm 29{ }^{14} \mathrm{C}\right.$ år bp, fig. 15 nr. 1). - Foto: Anna Tjelldén, Moesgaard Museum.

Antler axe found in Rya near Kraghede in Vendsyssel. It had lain on the bed of the watercourse and was found in a fishing net. The axe yielded the earliest ${ }^{14} \mathrm{C}$ date in the study $\left(3115 \pm 29{ }^{14} \mathrm{C}\right.$ years bp, fig. 15 no. 1$)$.

to Hvilshøjgårdøkser i 1905 blev fundet en hjortetaksøkse i et fiskegarn, der blev trukket op af Ryå ved Kraghede Fattiggård (fig. 2; fig. 15 nr. 1; fig. 19). Denne økse repræsenterer den ældste af de daterede hjortetaksøkser fra midten af ældre bronzealder og viser dermed tre separate nedlæggelser fra forskellig tid langs denne strækning af Ryå.

Jorløse Mose er en del af den store vestsjællandske Åmose. Moseområdet ligger i tilknytning til Tissø og gennemløbes af Halleby Å. I området er der fundet flere hjortetaksøkser. To af dem er dateret og blev fundet tæt på hinanden ved tørvegravning under 2. Verdenskrig inden for en mindre afgrænset del af mosen. Den ene er poleret og ornamenteret, mens den anden er poleret, men uden ornamentik (fig. 2; fig. 15 nr. $8 \_1$ og 8 2; fig. 5; fig. 20). Igen angiver dateringerne en tidsmæssig afstand, som peger på, at der kan være tale om to, separate nedlæggelser inden for det samme, afgrænsede område.

Noget lignende er også tilfældet ved fund fra den udtørrede Søborg Sø i Nordsjælland, hvor man allerede i slutningen af 1700-tallet påbegyndte et omfattende dræningsarbejde med henblik på indvinding af landbrugsjord. Arbejdet viste sig dog at være særdeles vanskeligt, og det var først i anden del af det 19. århundrede, at det blev færdiggjort. I forbindelse med det omfattende 
dræningsarbejde dukkede en del genstande op fra sten-, bronze-, og jernalder. Og desuden er der fundet flere sværd fra både vikingetid og middelalder. I sidste halvdel af 1800-årene fik arbejderne dusør for aflevering af opgravede genstande, hvilket betyder, at man på trods af mangelfulde fundoplysninger må regne med, at hovedparten af de fundne genstande blev afleveret. ${ }^{41} \mathrm{Iblandt}$ fundene fra søen er fire bronzealderlige hjortetaksøkser, hvoraf to er dateret. ${ }^{42}$ For begges vedkommende er der tale om upolerede typer med firkantet skafthul (fig. 2; fig. 15 nr. 7_1 og 7_2). Det er uvist, hvor de lå i forhold til hinanden i søen, men dateringerne ligger relativt langt fra hinanden i tid og er igen med til at vise, at man flere gange er vendt tilbage til Søborg Sø i deponeringsmæssigt øjemed - både i bronzealderen, men også i tidsperioderne før og efter. ${ }^{43}$

Samlet set medvirker dateringseksemplerne til en understregning af, at hjortetaksøkserne er en gruppe genstande, der forekommer som enkeltnedlæggelser, og at der er områder i landskabet, hvortil man gentagne gange er vendt tilbage for at deponere. Det er selvsagt kun de fundne og registrerede genstande, der er kendt, men det typologiske tilhørsforhold for nedlæggelser inden for samme, afgrænsede område og de her omtalte absolutte dateringer

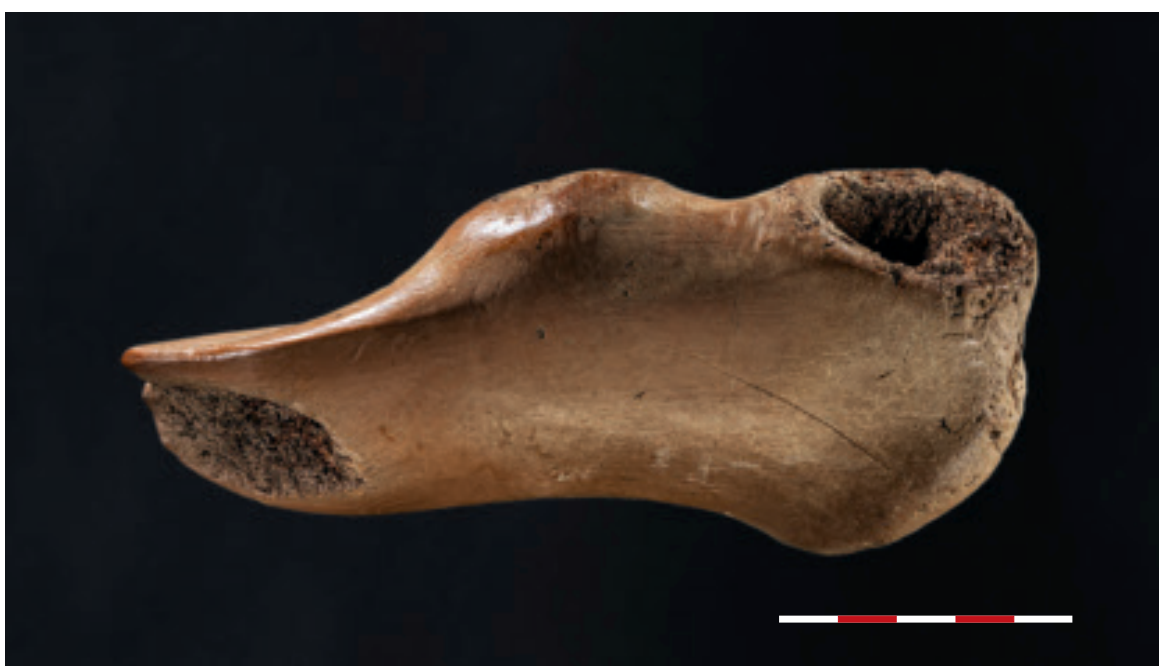

Fig. 20. Denne hjortetaksøkse er fundet ved tørvegravning i Jorløse Mose i Vestsjælland tæt ved øksen vist på fig. 5. Ud fra dateringerne og deres udseende ser de to imidlertid heller ikke ud til at være nedlagt samtidigt $\left(2797 \pm 28{ }^{14} \mathrm{C}\right.$ år bp). - Foto: Foto/Medie Moesgaard, Michael Johansen.

This antler axe was found during peat cutting in Jorløse Mose, western Zealand, close to the axe shown in figure 5 . The appearance of the axes and their dates indicate two separate depositions $\left(2797 \pm 28{ }^{14} \mathrm{C}\right.$ years bp). 
viser, at der kan være flere hundrede år imellem hver deponering. ${ }^{44}$ Landskab og måden at deponere på ser ud til at hænge sammen. Men det er svært at afgøre, om det i eksemplerne med gentagne nedlæggelser af hjortetaksøkser inden for det samme, afgrænsede område var bevidstheden om tidligere deponeringer langt tilbage i tid, der medførte nye nedlæggelser af hjortetaksøkser. Og/eller om det var særlige landskabstræk på stederne, der havde størst betydning for valg af nedlæggelsessted. Uanset hvad er det karakteristisk for deponeringer i bronzealderen, at nedlæggelsessteder ser ud til at knytte sig mere til zoner og områder f.eks. langs en å eller i en større mose end til specifikke, afgrænsede deponeringspladser eller kultsteder, der mere ser ud til at være et fænomen, som opstår med jernalderens deponeringspraksis. ${ }^{45}$

\section{Hjortetaksøkser i strømmende vand}

I europæisk sammenhæng udgør enkeltdeponeringer i floder - de såkaldte flodfund - en betydelig del af deponeringsmaterialet. ${ }^{46}$ Det samme gælder for hjortetaksøkser i europæisk kontekst, hvor mange af fundene knytter sig til strømmende vand. ${ }^{47}$

Som det fremgår af fig. 3, er der blandt det indsamlede materiale af danske hjortetaksøkser en betydelig gruppe, der er fundet $\mathrm{i}$ åer og søer, men samtidig i moser og engområder, som ligger i tæt tilknytning til åer. Fundforholdene hænger selvfølgelig sammen med gunstige bevaringsforhold i vand- og vådbundsområder, men der er samtidig nogle gennemgående træk i forhold til nedlæggelsesmiljøerne, der ser ud til at afspejle en reel forhistorisk situation, idet de danske vådbundsfundne hjortetaksøkser er langt mere knyttet til åer og åmiljøer end til mere isolerede kedelmoser eller lignende. Dette træk er fremgået af de gennemgåede fundsituationer, og endnu et typisk eksempel herpå ses af fig. 22, hvor to ret ens hjortetaksøkser (fig. 21a og b) - både i udseende og datering - er fundet inden for ca. 1,5 km's afstand i og ved Uggerby $\AA$ i Vendsyssel. Den ene af økserne er registreret som et åfund, mens den anden er fundet i engområdet under 100 meter fra åen. I et landskab før dræningen har sådanne ånære engområder ofte kunnet fremstå mere sumpede end i dag, og har måske også på den måde været opfattet som tæt relateret til selve åforløbet, hvilket principielt kunne gælde for eksemplet fra Uggerby Å. Under alle omstændigheder underbygges billedet af en ånær relation for fund af hjortetaksøkser, hvis man ser lidt mere detaljeret på fundforholdene for de hjortetaksøkser, der indgår i de første tre søjler i fig. 3 (å, sø og eng/mose). Ud af samlet 112 fund i de tre fundkategorier var fundoplysningerne så tilpas detaljerede i 102 af tilfældene, at det var muligt på digitaliserede, historiske 

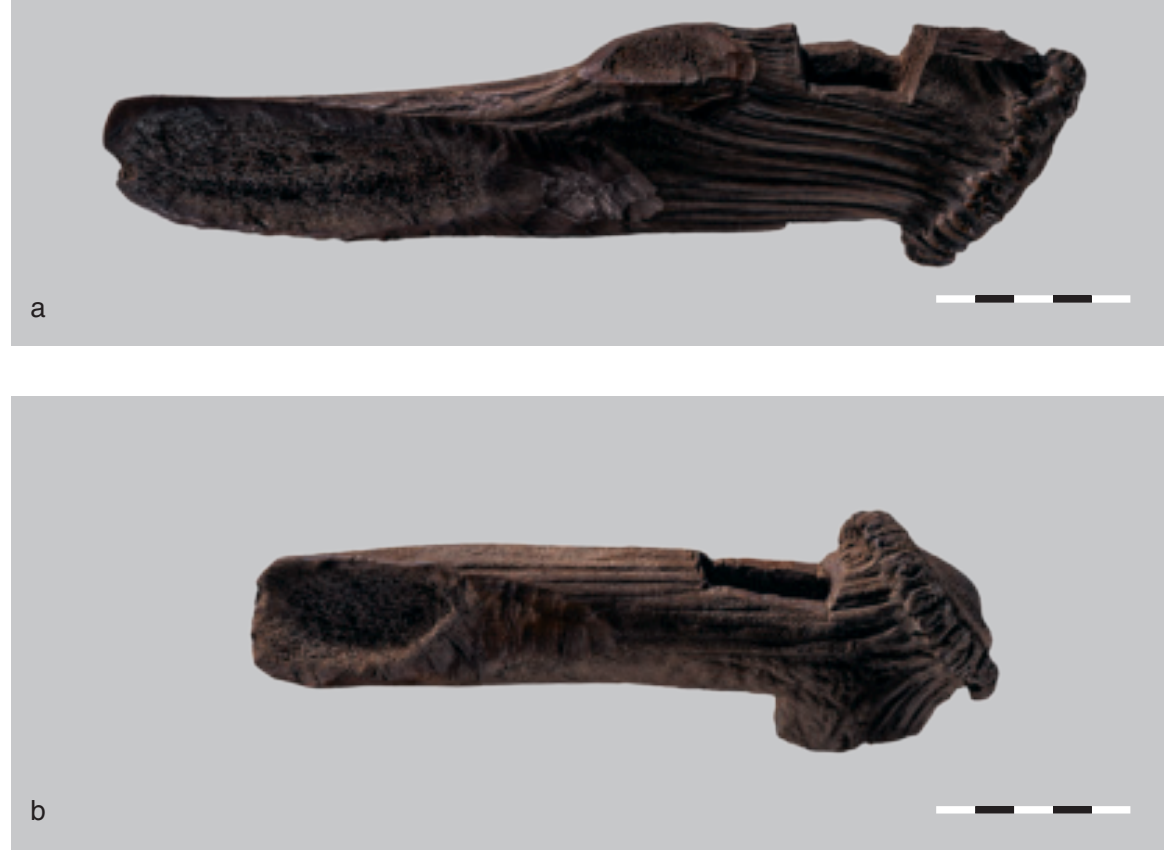

Fig. 21a og b. To hjortetaksøkser fra Uggerby Å i Vendsyssel. De to ret ens eksemplarer (upolerede og med firkantede skafthuller), som er næsten samtidige, kan være nedlagt inden for kort tid, men de befinder sig dog så langt fra hinanden geografisk (ca. 1,5 km jf. fig. 22), at der formentlig er tale om nedlæggelser foretaget af to forskellige bebyggelsesenheder. I begge tilfælde er der i øvrigt tale om, at råmaterialet til økserne har været kastestang, da området ved rosenkransen er der bevaret (21a: $2579 \pm 28{ }^{14} \mathrm{C}$ år bp, $21 \mathrm{~b}: 2514 \pm 24{ }^{14} \mathrm{C}$ år bp). - Fotos: Michael Johansen, Foto- og Medieafdelingen, Moesgaard Museum.

Two antler axes found in Uggerby $\AA$ in Vendsyssel. The dates lie close to each other and the two axes are typologically similar (unpolished and with rectangular shaft-holes) so their deposition could have taken place simultaneously. The geographical distance between them $($ c. $1.5 \mathrm{~km})$ suggests, however, that two different settlements were responsible. In the case of both axes, the area around the burr shows that they were made from shed antlers (21a: $2579 \pm 28{ }^{14} \mathrm{C}$ years bp, 21 b: $2514 \pm 24{ }^{14} \mathrm{C}$ years bp).

kort at foretage afstandsmålinger i meter til henholdsvis nærmeste eng/mose, å og sø. ${ }^{48}$ Åfundene er typisk brednære, og dermed knytter flere af hjortetaksøserne sig til et eng-/mosemiljø og et å-miljø på én og samme gang. I figur 23 ses måledata fra de 102 hjortetaksøkser, hvor x-aksen repræsenterer åfund og y-aksen fund fra søer. Der kan gemme sig flere uregistrerede søfund, men ud fra det foreliggende materiale fremgår det dog af diagrammet, at langt hovedparten af fundpunkterne knytter sig meget tæet til x-aksen og dermed 


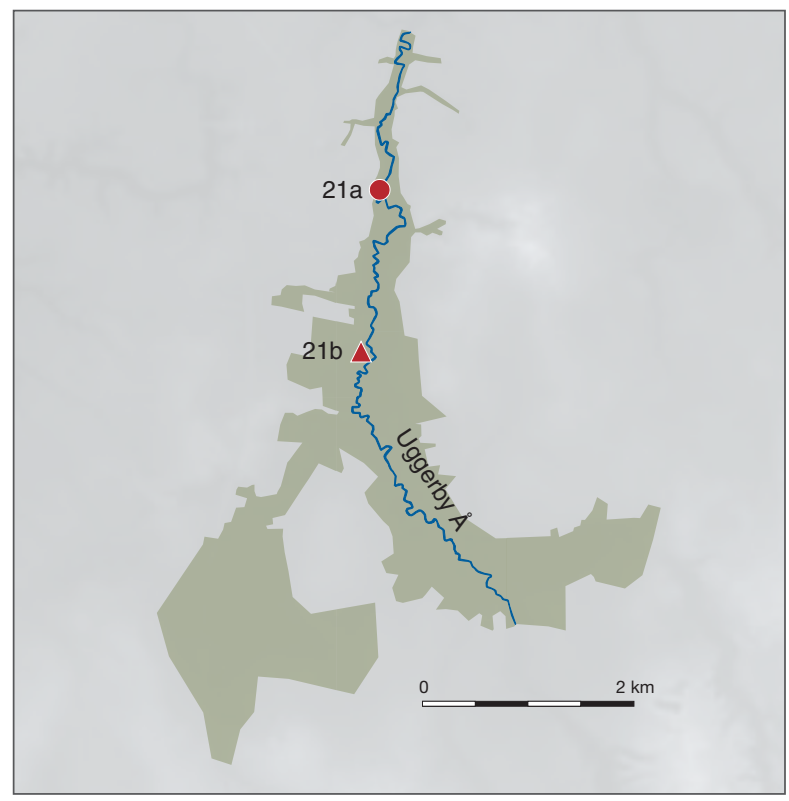

Fig. 22. Kortet er en digitalisering af henholdsvis Uggerby $\AA$ og det omgivende engområde (Høje Målebordsblade) med placering af de to hjortetaksøkser (fig. 21a og b), hvor den øverste er fig. 21a, som er fundet i ån (derfor angivet med cirkelsymbol), mens fig. $21 \mathrm{~b}$ er fundet i engområdet op til åen (angivet med trekantsymbol) og angiver dermed et eksempel på den meget tætte relation til strømmende vand, som er et gennemgående træk ved hjortetaksøksernes nedlæggelsessteder. - Grafik: Lise Frost.

Digitised topographical map of Uggerby $\AA$ and the adjoining meadow area (excerpt from a historical topographical map, 1870) showing the location of the two antler axes (fig. 21a-b). Figure 21a, at the top, was found in the watercourse (marked with a circle) and figure $21 \mathrm{~b}$ was found in the adjacent meadow area (marked with a standing triangle), thereby giving an example of the close relation to running water.

til et eng-/mose-/å-miljø, hvilket således både antyder, at flere hjortetaksøkser end de i fig. 3 angivne 42 åfund oprindeligt blev nedlagt i en å, og at der både geografisk og kronologisk gennemgående er en vis grad af uniformitet i de landskabsmiljøer, der blev valgt som deponeringssted.

\section{Afsluttende bemærkninger}

Hjortetaksøkser fra bronzealderen udgør en del af den lidt oversete gruppe af genstande af organiske materialer, som indimellem indgår i periodens depotfund. En fundgruppe, hvor fokus typisk er rettet mod metallerne. For nogle hjortetaksøksers vedkommende er der tale om relativt enkelt udførte økser uden polering og ornamentik, mens der i andre tilfælde ses adskillige orna- 


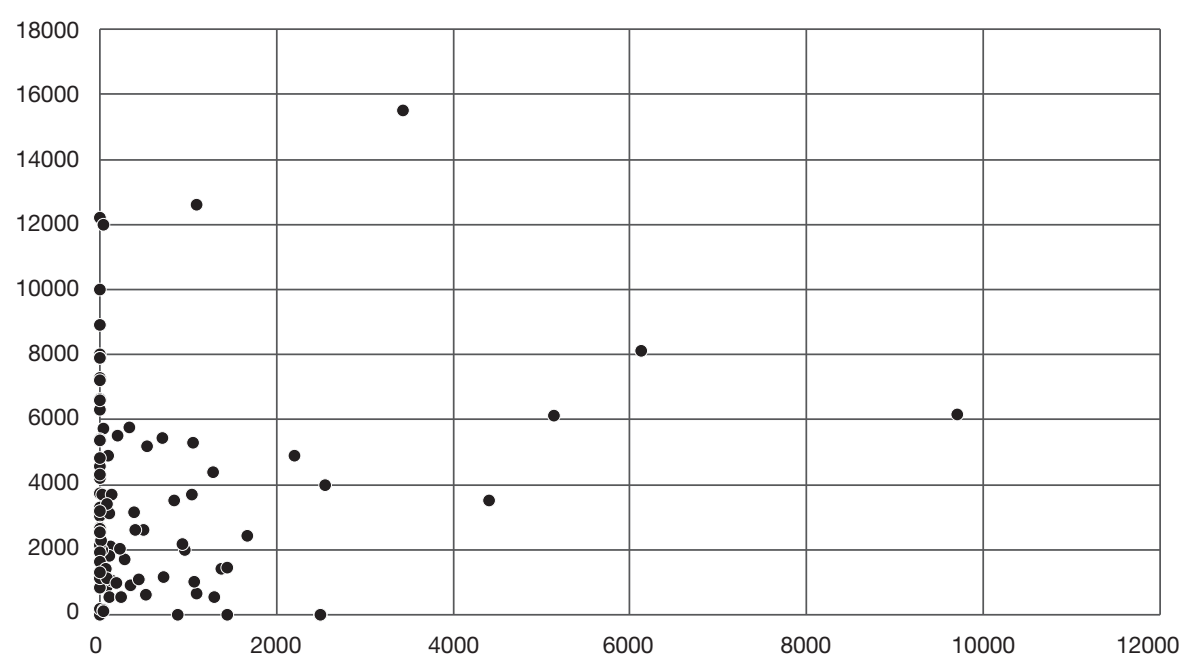

Fig. 23. Diagram over 102 målinger af hjortetaksøksernes afstandsmæssige relation til nærmeste å/sø, som viser, at hjortetaksøkserne er stærkt knyttet til åmiljøer. X-aksen viser å-afstand i meter og y-aksen afstanden i meter til nærmeste sø. - Grafik: Mette Løvschal og Lise Frost.

Diagram summarising the distances of find sites of antler axes (102 records) from the nearest river/lake, showing that the antler axes are closely associated with meadow/bog/ river areas. The $\mathrm{x}$-axis shows the distance in metres to the nearest watercourse and the $\mathrm{y}$-axis shows the distance to the nearest lake.

mentikdetaljer, der også i yderst sjældne sammenhænge kan indbefatte metalindlæegning. Muligheden for at inddrage ${ }^{14} \mathrm{C}$-dateringer i forbindelse med en analyse af deponeringerne har dels kunnet vise, at der med hjortetaksøkserne er tale om en genstandsgruppe, som hører til i både ældre og yngre bronzealder. Dels har dateringerne i deponeringsmæssig sammenhæng kunnet bidrage til en påvisning af, at hjortetaksøkser typisk nedlægges som enkeltdeponeringer, hvor man indimellem er vendt tilbage til de samme områder for at gentage en deponering - nogle gange med lange tidsmæssige intervaller. Typiske fundsteder er åer samt mose- og engområder, der ofte grænser op til åer og antyder, at en del flere end de registrerede åfund oprindelig blev deponeret i strømmende vand.

\section{NOTER}

1. Harding 2000; Thrane 2011; Hansen et al. 2012; Bradley 2013.

2. Nærværende artikel er en væsentlig forkortet udgave af en engelsksproget artikel rettet til tidsskriftet Prähistorische Zeitschrift (Frost 2019), men har bl.a. mere metodisk fokus på trinvis prøvetagning ved ${ }^{14} \mathrm{C}$-datering samt metalanalyse i forbindelse med hjortetaksøkser (jf. medforfattere fra disse analyser, hvor Marie Kanstrup har 
stået for ${ }^{14} \mathrm{C}$-analyser og Gry H. Barfod for XRF-analyser af metal). Projektet er muliggjort via bevilling fra: Kulturministeriets Forskningsudvalg (KFU) i 2017, hvor ${ }^{14} \mathrm{C}$-analyser endvidere er delvist finansieret af bevillinger fra Dronning Margrethe II's Arkæologiske Fond og Beckett-Fonden.

3. Torbrugge 1996; Hansen 2000; Falkenstein 2005; Huth 2011; Frost 2015.

4. Se f.eks. Müller 1895, nr. 275, nr. 445 \& 456.

5. Jensen 1973; Willroth 1985, s. 21; Bodilsen 1989; Karsten 1994, s. 21f; Koch 1998, s. $157 \mathrm{f}$.

6. Müller 1921, s. 6.

7. Fx: Lange 1926; Broholm 1949, s. 192ff.; Mathiassen 1942, s. 14; Brøndsted 1958, s. 258ff.; Christiansen \& Hansen 1993; Kaul 2010; Johansen 2016.

8. Schmidt 1995.

9. Frost 2019.

10. Katalog over de indsamlede økser findes i Frost 2019. Indsamlingen har krævet et større registreringsarbejde, idet mange af bronzealdertyperne tidligere er blevet registreret som stenalderfund. De involverede museer takkes for stor hjælp og imødekommenhed i forbindelse med arbejdet.

11. Müller 1891, s. 23; Lange 1926, s. 43 Abb. 2; Christiansen \& Hansen 1993, s. 87; Schmidt 1995, s. 74 nr. 8; Thrane 2009, s. 37; Frost 2019, C21.

12. Stjernquist 1961, s. 85; Stjernquist 1969, s. 129f; Bertemes 1989, s. 99; Schmidt 1995, s. 57 Abb. 1; Lauwerier 1999; Luik 2011; Luik 2013.

13. Frost 2019, Tab. 2.

14. Broholm 1934; 1935; Glob 1938, s. 60 Fig. 22; Brøndsted 1958, s. 259.

15. Glob 1969, s. 244ff.; Kjærum 1990, s. 76; Nyegaard 1996, s. 54; Kaul 2010, s. 87.

16. Luik 2011, s. 36.

17. Kaul 2010, s. $86 \mathrm{ff}$.

18. Johansen 2016.

19. Jensen 2001; Malmros 2001.

20. Müller 1895, s. 23 Fig. 140.

21. Müller 1921, s. 6; Glob 1938, s. 55; Broholm 1949, s. 192; Brøndsted 1958, s. 260.

22. Ilkjær 1990, s. 32ff.

23. Schmidt 1995, s. 85 nr. 5.

24. Kaul 2010.

25. Johansen 2016.

26. Mathiassen 1942, s. 12f, fig. 9; Schmidt 1995, s. 73 nr. 1.

27. Hall 1960; Fitzgerald 2008. Mikro-røntgensfluorescens-analyse ( $\mu$-XRF) er foretaget af Gry H. Barfod ved Aarhus Geochemical and Isotope Research (AGIR) Platform.

28. Boye 1986, s. 76, 84, 116.

29. Stjernquist 1958

30. Behrens 1952, s. 292; Schrickel 2012, s. 101f Abb. 3 \& 4.

31. Kaul 2010; Johansen 2016, s. 149.

32. Tak til de involverede museer, som har givet tilladelse til prøveudtagning, tak til laboranterne ved Aarhus AMS Center samt til konservator Anna Tjelldén, Moesgaard Museum for hjælp ved bestemmelse af egnet sted for prøveudtagning og til konser- 
vator Signe Nygaard for hjælp ved prøvetagning af økser fra Nationalmuseet. I fig. 15 er tre dateringer markeret med en stjerne, som angiver, at dateringerne af disse tre ikke er foretaget i indeværende projekt. Tak til Louise Lund Johansen (Nordsjællands Museum) fig. 15 nr. 12; Mogens Bo Henriksen (Odense Bys Museer) fig. 15 nr. 13 og Peter Vang Petersen (Nationalmuseet) fig. 15 nr. 16 for at dele resultaterne af ${ }^{14} \mathrm{C}$-dateringer af de tre hjortetaksøkser.

33. Den anvendte forbehandling følger anbefalingerne i Brown et al. (1988), hvor der foretages ultrafiltrering for at sikre datering af det, som mest mulig ligner in vivo kollagen. For mere detaljeret gennemgang af ${ }^{14} \mathrm{C}$-datering ved Aarhus AMS Center henvises til Olsen et al. 2016 og Philippsen 2017.

34. Johansen 2016, s. 153.

35. Forkortelsen står for: Elemental analysis isotope ratio mass spectronomy.

36. Bevaringstilstanden for den enkelte økse er både blevet vurderet op imod eksempler på knogleprøver med lavt kollagenudbytte (gennemsnitlig ca. $3 \%$ ) og knogleprøver med et højere kollagenudbytte (gennemsnitlig ca. 8\%). Analyserne viste, at den gennemsnitlige kvælstofkoncentration i de analyserede testprøver fra hjortetaksøkserne lå på 4,8\% $\pm 0,4$, mens det gennemsnitlige kollagenudbytte lå på 7,4\% $\% 2,7$, hvilket understreger, at hjortetaksøksernes bevaringsgrad er god.

37. http://www.kulturarv.dk/fundogfortidsminder/

38. Se f.eks. Becker 1964; Jensen 1997, s. 278 f nr. 2.

39. Jensen 1973; Bodilsen 1989.

40. Müller-Wille 1999, s. 21f; Frost 2015; Frost 2019.

41. Boye 1882, s. 14. Arkæologen Jørgen Jensen inddrog således bl.a. bronzealderens periode V-metalfund fra Søborg Sø (herunder bl.a. et hængekar og tre celte) i sin væsentlige argumentation for betydningen af enkeltdeponeringer i bronzealderens deponeringspraksis, jf. Jensen 1973, s. 147.

42. Jensen 1997, s. 166ff.

43. Boye 1882.

44. Gosden \& Lock 1998, s. 3ff.; Koch 1998, s. 157f; Müller-Wille 1999, s. 21f; Fontijn 2012, s. 51ff.; Frost 2015, s. 39ff.

45. Johannesen 2016, s. $216 \mathrm{ff}$.

46. Se f.eks. Torbrugge 1996; Hansen 2000; Huth 2011.

47. Schmidt 1995, s. 62.

48. Her er anvendt de såkaldte høje målebordsblade fra sidste halvdel af 1800-tallet.

\section{LITTERATUR}

Becker, C.J. 1964: Neue Hortfunde aus Dänemark mit frühe bronzezeitlichen Lanzenspitzen. Acta Archaeologica 35, s. 115-152.

Bertemes, F. 1989: Das Frühbronzezeitliche Gräberfeld von Gemeinlebarn. Kulturhistorische und Paläometallurgische Studien. Text und Katalog. Bonn.

Bodilsen, I. 1989: Enkeltfund - votivfund i dansk bronzealder. Kuml 1987, s. 87-104.

Boye, V. 1882: Fund af Gjenstande fra Oldtiden og Middelalderen i og ved Søborg Sø.

Kjøbenhavn.

Boye, V. 1986: Fund af Egekister fra Bronzealderen i Danmark. Fotografisk genoptryk med efterskrift af Mogens Ørsnes. Højbjerg. 
Bradley, R. 2013: Hoards and the Deposition of Metalwork. I: H. Fokkens \& A. Harding (eds.): The Oxford Handbook of the European Bronze Age. Oxford, s. 121-139.

Broholm, H.C. 1934: Øxeskafter af Træ og Horn fra Danmarks Bronzealder. Aarbøger for Nordisk Oldkyndighed og Historie, s. 123-128.

Broholm, H.C. 1935: Enkeltfund fra Bronzealderen. Aarbøger for Nordisk Oldkyndighed og Historie, s. 257-264.

Broholm, H.C. 1949: Danmarks Bronzealder. Danmarks Kultur i den yngre Bronzealder. Fjerde bind. København.

Broholm, H.C. 1953: Danske Oldsager. IV Yngre bronzealder. København.

Bronk Ramsey, C. 2009: Bayesian analysis of radiocarbon dates. Radiocarbon, 51(1), s. 337-360.

Brown, T.A., D.E. Nelson, J.S. Vogel \& J.R. Southon 1988: Improved Collagen Extraction by Modified longin Method. Radiocarbon 30:2, 171-177.

Brøndsted, J. 1958: Danmarks Oldtid. Bronzealderen. II bind. København.

Christiansen, D.V. \& S.S. Hansen 1993: En affaldsgrube fra yngre bronzealder ved Ganløse. Arkcologi i Frederiksborg Amt 1983-1993, s. 81-94.

Falkenstein, F. 2005: Zu den Gewässerfunden der älteren Urnenfelderzeit in Süddeutschland. I: B. Hänsel et.al (eds.): Interpretationsraum Bronzezeit: Bernhard Hänsel von seinen Schülern gewidmet. Bonn, s. 491-504.

Fitzgerald, S. 2008: Non-destructive micro-analysis of art and archaeological objects using micro-XRF. Archeometriai Mühely, 3, s. 75-80.

Fontijn, D.R. 2012: Landscapes without boundaries? Some thoughts on Bronze Age deposition areas in north-west Europe. I: S. Hansen, D. Neumann \& T. Vachta (eds.): Hort und Raum. Aktuelle Forschungen zu bronzezeitliche Deponierungen in Mitteleuropa. Berlin, s. 49-68.

Frost, L. 2015: River finds - Bronze Age depositions from the River Gudenå, Denmark. Germania 91, 2013, s. 39-87.

Frost, L. 2019 in prep.: The Danish Bronze Age antler axes - depositions in time and space. Prähistorische Zeitschrift.

Glob, P.V. 1938: Stenredskaber fra Bronzealderen. I: H. Norling-Christensen \& P.V. Glob (red.): Winther-Festskrift. København, s. 40-74.

Glob, P.V. 1969: Helleristninger i Danmark. Højbjerg.

Gosden, C. \& G. Lock 1998: Prehistoric histories. World Archaeology, 30 (1), s. 2-12.

Hall, E.T. 1960: X-ray fluorescent analysis applied to archaeology. Archaeometry, 3(1), s. 29-35.

Hansen, S. 2000: Gewässerfunde im bronzezeitlichen Europa. Ein Panorama. Das Altertum 46, s. 31-62.

Hansen S., D. Neumann \& T. Vachta (Hrsg.) 2012: Hort und Raum. Aktuelle forschungen zu Bronzezeitlichen Deponierungen in Mitteleuropa. Berlin/Boston.

Harding, A. 2000: European societies in the Bronze Age. Cambridge.

Huth, C. 2011: Wasser zwischen den Welten - Überlegungen zum archäologischen Quellenwert einer bronzezeitlichen Flusslandschaft. I: Felix Bittman, Johannes Ey, Martina Karle, Hauke Jöns, Erwin Strahl \& Steffen Wolters (eds.): Marschenratskolloquium 2009. Flüsse als Kommunikations- und Handelswege / Marschenrat Colloquium 2009. Rivers as Communication and Trade Routes. Rahden/Westf., s. 47-57.

Jensen, G. 2001: Macro wear patterns on Danish late Mesolithic antler axes. In: A.M. 
Choyke \& L. Bartosiewicz (eds.): Crafting bone - Skeletal technologies through time and space. Oxford, s. 165-170.

Jensen, J. 1973: Ein neues Hallstattschwert aus Dänemark. Beitrag zur Problematik der jungbronzezeitlichen Votivfunde, Acta Archaeologica 43, 1972, s. 115-164.

Jensen, J. 1997: Fra Bronze- til Jernalder. En kronologisk undersøgelse. København.

Johannesen, K. 2016: Rituals of Common Things. The ritual and religion of the mixed wetland deposits in the early Iron Age of Southern Scandinavia. Ph.D. dissertation, Aarhus University. Aarhus.

Johansen, L.L. 2016: Sort på hvidt. Alle tiders Nordsjelland. Museum Nordsjellands Årbog, s. $149-154$.

Karsten, P. 1994: Att kasta yxan i sjön: en studie över rituell tradition och förändring utifrån skånska neolitiska offerfynd. Stockholm.

Kaul, F. 2010: Hjortetaksøkse fra Bonderup Bro. I: M. Andersen \& P.O. Nielsen (red.): Danefo - skatte fra den danske muld. København, s. 85-89.

Kjærum, P. 1990: Hjortedrabet. I: P. Kjærum \& R.A. Olsen (red.): Oldtidens ansigt. Højbjerg, s. 76.

Koch, E. 1998: Neolithic Bog Pots from Zealand, Møn, Lolland and Falster. København.

Lange, H. 1926: Hirschgeweihäxte. Prähistorische Zeitschrift 17, 1926, s. 33-50.

Lauwerier, R.C.G.M. 1999: A Bronze og Iron Age antler axe with rectangular shafthole. I: C. Becker et al. (eds.): Historia animalium ex ossibus. Beiträge zur Paläoanatomie, Archäologie, Ägyptologie, Ethnologie und Geschichte der Tiermedizin. Rahden/Westf., s. 225-228.

Luik, H. 2011: Material, technology and meaning: antler artefacts and antler working on the eastern shore of the Baltic Sea in the late Bronze Age. Estonian Journal of Archaeology, 2011, 15, 1, 1, s. 32-55.

Luik, H. 2013: Late Bronze Age bone crafting in the Eastern Baltic: standardization of artefact types and individual ingenuity. Estonian Journal of Archaeology 17, 1, s. 24-37.

Malmros, C. 2001: Bestemmelse af trærester i æggen på hjortetaksøkser fra Ertebøllekultur. Nationalmuseets Naturvidenskabelige Undersøgelser, NNU-rapport nr. 5. København.

Mathiassen, T. 1942: Et Udvalg af Aarets Mosefund. Fra Nationalmuseets Arbejdsmark, s. $5-16$.

Müller, S. 1895: Ordning af Danmarks Oldsager. Stenalderen, Bronzealderen, Jernalderen (tekst og tavler) 1888-1895. Kjøbenhavn.

Müller, S. 1921: Oldtidens kunst i Danmark. Bronzealderens Kunst. Bd. II. Kjøbenhavn.

Müller-Wille, M. 1999: Opferkulte der Germanen und Slawen. Stuttgart.

Nyegaard, G. 1996: Faunalevn fra bronzealder. En zooarkcologisk undersøgelse af sydskandinaviske bopladsfund. Utrykt Ph.d.-afhandling, Københavns Universitet. København

Olsen, J. et al. 2016: Radiocarbon analysis on the new AARAMS1MV Tandetron, Radiocarbon 59(3), s. 905-913.

Philippsen, B. 2017: Problems in radiocarbon dating. I: M. Sørensen \& K. Buck Pedersen (eds.): Problems in Palaeolithic and Mesolithic Research. Aarhus, s. 105-117.

Reimer, P.J. et al. 2013: IntCal13 and Marine13 Radiocarbon Age Calibration Curves 0-50,000 Years cal BP, Radiocarbon 55(4), s. 1869-1887.

Schmidt, J.-P. 1995: Drei jungbronzezeitliche Geweihäxte aus Schleswig-Holstein. Ein Beitrag zur Geschichte punktkreisverzierter Hirschgeweihäxte. Offa, s. 57-86. 
Stjernquist, B. 1958: Ornamentation métallique sur vases d'argile. Meddelanden från Lunds universitets historiska museum, s. 107-169.

Stjernquist, B. 1961: Simris II. Bronze Age Problems in the Light of the Simris Excavation. Lund.

Stjernquist, B. 1969: Beiträge zum Studium von Bronzezeitlichen Siedlungen. Bonn/Lund.

Thrane, H. 2009: Sekstusinde brcendte oldsager. Frederik den Syvendes tabte oldsagssamling på Frederiksborg Slot. Dansk tidsskrift for Museumsformidling, nr. 29. Højbjerg.

Thrane, H. 2011: Contacts between Central and northern Europe. I: H. Meller \& F. Bertemes (eds.): Der Griff nach den Sternen. Internationales Symposium in Halle (Saale) 16.-21. Feb. 2005. Halle, s. 579-590.

Willroth, K.H. 1985: Die Hortfunde der älteren Bronzezeit in Südschweden und auf den dänischen Inseln. Neumünster. 


\section{Bronze Age antler axes - dating and depositional context}

Antler axes are typically associated with the Mesolithic, but this article presents a group of antler axes from the Danish Bronze Age, when this artefact type surprisingly turns up again after an absence from the tool inventory of more than 2000 years (fig. 1).

These artefacts may be found in pits in a settlement context, but the typical finds contexts for the 155 recorded Bronze Age antler axes are rivers/watercourses, lakes and wetland areas, where the axes have been deposited individually, in line with the Bronze Age's other major group of singly-deposited objects (figs. 2-3). This close relationship with water is linked to the European river finds, as antler axes are not solely a Danish phenomenon but are found across large parts of Europe during the Bronze Age, with the axes typically being deposited singly in running water. In both a Danish and a European context, the axes disappear again in the Iron Age.

This article gives an account of the Danish antler axes in relation to their distribution, finds circumstances and typological characteristics, together with a couple of metal analyses and several new ${ }^{14} \mathrm{C}$ dates for antler axes. The antler axes from the Bronze Age vary in appearance; they may or may not be polished and may or may not be ornamented. They do though have certain features in common, for example they are characterised by a down-turned butt. The shaft-hole can either be round or rectangular and is located a long way back on the axe. They were typically hafted as axes rather than adzes, and their ornamentation frequently consists of point-circle motifs, where pitch has been inlaid to give contrast (figs. $4-8$ ). In a very few cases, metal may form part of the ornamentation. Two results are presented here of micro-XRF analyses of, respectively, inlays of tin and bronze (figs. 9-14).

A significant part of the project focussed on dating of the Bronze Age antler axes. Only a couple of dates had been published previously, both of which fell in the Late Bronze Age. The new dates clearly show, however, that antler axes are a very consistent phenomenon through both the Early and the Late Bronze Age. Dating involves drilling material out for analysis, and in the case of antler and bone there is sometimes a requirement for a sample of as much as $600-800 \mathrm{mg}$ for a date to be obtained. To avoid drilling unnecessary holes in the often aesthetically impressive and eminently exhibitable artefacts such as these, a staged methodological approach was adopted in this project, which involved two-step sampling for radiocarbon dating. Firstly, a very small sample of 5-20 mg was taken for a socalled EA-IRMS analysis. This reveals the preservation condition of the material and thereby the amount of material required to obtain an actual ${ }^{14} \mathrm{C}$ date. In all cases, this preliminary analysis showed that only $100 \mathrm{mg}$ of material had to be drilled out for the actual dating process. This method can therefore be warmly recommended for the dating of bone and antler objects such as these (figs. 15-16).

The dates have revealed that antler axes are present in both the Early and the Late Bronze Age. Moreover, the dates could be used in a clarification of the depositional 
circumstances. As already mentioned, the antler axes typically represent single depositions, but sometimes two axes are found relatively close together and, based on the finds circumstances, are therefore interpreted as single-type depositions. It has now been possible in some cases to date both axes: For example antler axes found together in sediment dug up during the dredging of rivers/watercourses (Ryå and Odense $\AA$ ), or discovered close together during peat cutting (Jorløse Mose) or within the same area of reclaimed lake (Søborg Sø). The dates obtained in these cases suggest that these finds represent repeated single depositions within the same area rather than simultaneous deposition of two axes. The phenomenon of returning, in a depositional context, to specific areas in the natural landscape, sometimes at intervals of several hundred years, appears to be a general feature of the Bronze Age - both in Denmark and in Europe as a whole (figs. 17a-22).

\section{Lise Frost \\ Moesgaard Museum \\ Gry H. Barfod \\ Aarhus Geochemistry Isotope Research (AGiR) \\ Institut for Geoscience \\ Aarhus Universitet \\ Marie Kanstrup \\ Aarhus AMS Centre \\ Institut for Fysik og Astronomi \\ Aarhus Universitet}

